SD 143

A 42

\title{
PRACTICAL FORESTRY
}

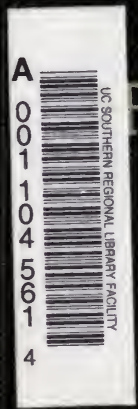

IN THE

ACIFIC NORTHWEST 


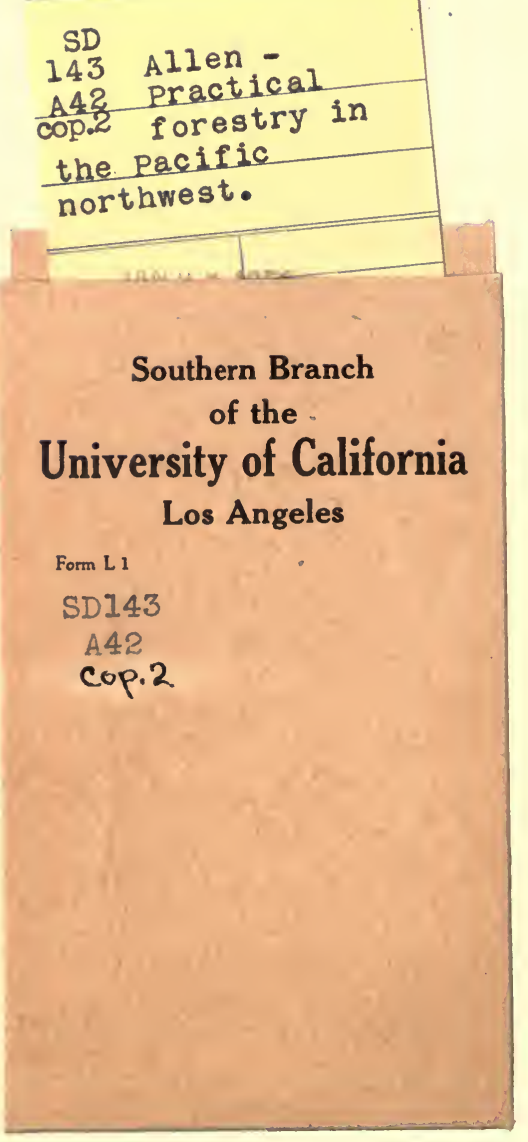




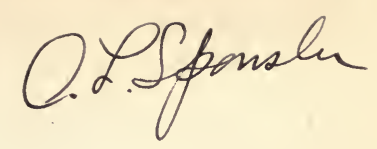

This book is DUE on the last date stamped below DEC I 71924 APR $9 \quad 1925$ AFR 2) Q JGC: APR 19.1929 NOV $24: 930$

MAY I 21928 DEC 51930 JUN 3 1925 MAR -21920 JAN 51931 $\begin{array}{llll}\text { APR } 9 & 1926 & \text { MAY } 4 & 1932\end{array}$

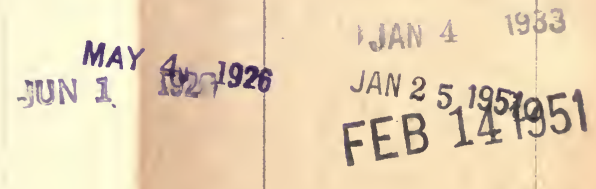
DEO $6 \quad 1920$ TEC T 1922 



\section{PRACTICAL FORESTRY}

IN THE

\section{PACIFIC NORTHWEST}

PROTECTING EXISTING FORESTS AND GROWING NEW

ONES, FROM THE STANDPOINT OF THE PUBLIC

AND THAT OF THE LUMBERMAN, WITH AN

OUTLINE OF TECHNICAL METHODS.

BY

E. T. ALLEN

Forester for the Western Forestry \& Conservation Association (Formeriy

U. S. District Forester for Oregon, Washington and Alaska)

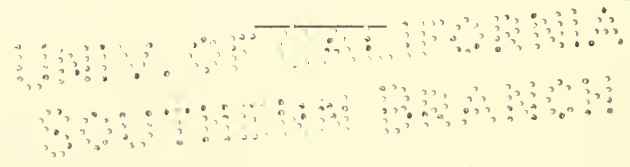

ISSUED BY

THE

WESTERN FORESTRY \& CONSERVATION ASSOCLATION

Office of the Forester

421 Yeon Building, Portland, Oregon.

1911

\section{2}


S.

s. 


\section{$S D$ \\ 143 \\ A 42 \\ $\operatorname{cop} 2 \pi$}

\section{PREFACE}

\section{WHAT THIS BOOK IS ABOUT AND WHY}

The object of this booklet is to present the elementary principles of forest conservation as they apply on the Pacifie coast from Montana to California.

There is a keen and growing interest in this subject. Citizens of the western states are beginning to realize that the forest is a community resource and that its wasteful destruction injures their welfare. Lumbermen are coming to regard timber land not as a mine to be worked out and abandoned, but as a possible source of perpetual industry. They find little available information, however, as to how these theories can be reduced to actual practice. The Western Forestry and Conservation Association believes it can render no more practical service than by being the first to outline for public use definite workable methods of forest. management applicable to western conditions.

A publication of this length can give little more than an outline, but attempt has been made either to answer the most obvious questions which suggest themselves to timber owners interested in forest preservation or to guide the latter in finding their own answers. Only the most reliable conservative information has been drawn on, much of it having been collected by the Government.

While the booklet is intended to be of use chiefly- to forest owners, a chapter on the advantage to the community of a proper state forest policy is included, also a chapter on tree growing by farmers. The first presents the economic relation of forest preservation to public welfare, with its problems of fire prevention, taxation and reforestation; for 
the use of writers, legislators, voters, or others desiring to investigate this subject of growing public concern. It is based upon the conclusions of the best unprejudiced authorities who have approached these problems from the public standpoint.

In the technical chapters on forest management and its possibilities, the author accepts full responsibility for conclusions drawn except when otherwise noted. To the Forest Service, however, is entitled the credit for collecting practically all the growth and yield figures upon which these conclusions are based. Especial acknowledgement is due to Mr. J. F. Kümmel for information on tree planting.

In concluding this preface, the author regrets that the booklet which it introduces was necessarily written hurriedly, a page or two at a time, at odd hours taken from the work of a busy office. For this reason its style and management leaves much to be desired, but it has been thought better to make the information it contains immediately available than to await a doubtful opportunity to rewrite it. 


\title{
CONTENTS
}

\author{
PREFACE
}

What This Book Is About, and Why................

\section{INTRODUCTION}

What We Have in the West. What We Are Doing With It.

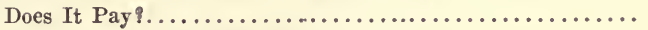

CHAPTER I. FORESTRY AND THE PUBLIC

Importance of Forests as a Community Resource. Wealth Their Manufacture Brings to All Industries. Value as Source of Tax Revenue. Our Interest as Consumers. Real Issue Not Property Protection bnt Conditions of Life for All. Particularly Favorable Natural Forest Conditions on Pacific Coast. Present Policy of Waste. Fire Loss. Idleness of Deforested Land. Action We Must Take. Fire Prevention. Reforestation. Tax Reform. Public Responsibility. Essentials of Needed State Policy. Duty of the Average Citizen.

CHAPTER II. FORESTRY AND THE LUMBERMAN

Economic Principles Governing Forest Production. Supply and Demand. Lumberman Must Consider Both Profit of Forestry and Popular Demand for Its Practice. Consumer Must Pay for Growing Timber. Attitude of State Will Become More Encouraging. How All This Affects the Lumberman. Should Plan for Meeting the Situation. Circumstances that Determine Profit. Who Can Afford to Reforest Cut-over

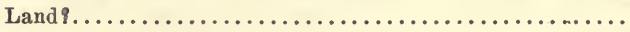

CHAPTER III. FORESTRY AND THE FOREST

Technical and Practical Problems. Elementary Principles of Forest Growth. Fundamental Systems of Management. Nature as a Model. Logging to Insure Another Crop. Natural and Artificial Reproduction. Details of Management for Each Western Species. Seeding and Planting. Costs and Carrying Charges. Rate of Growth. Probable Financial Returns. Hardwood Experiments.............. 
CHAPTER IV. FORESTRY AND THE FIRE HAZARD

The Slashing Menace. Brush Piling. Slash Burning. Fire Lines. Spark Arrestors. Patrol. Associate Effort. Young Growth

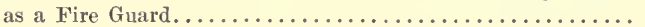

CHAPTER V. FORESTRY AND THE FARMER

Cutting Methods on the Wooded Farm. Best Use of Poor Forest Land. The Handling of Fire in Clearing. Planting on Treeless Farms. Species Most Promising for Fuel and Improvement Material. Windbreaks to Prevent Evaporation of Soil Moisture. Methods and Cost of Tree Growing...... 104

APPENDIX

Tax Reforms to Permit Reforestation. Opinions of Expert Authorities............................... 113

The Western Forestry and Conservation Association. Its Organi-

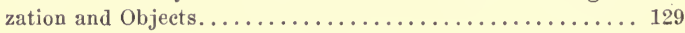




\title{
- INTRODUCTION
}

\section{WHERE WE STAND TODAY}

\author{
What We Have
}

The five states of Montana, Idaho, Washington, Oregon and California contain half the merchuntable timber in the United States today-a fact of startling economic significance. It means first of all that here is an existing resource of incalculable local and national value. It means also that here lies the most promising field of production for all time. The wonderful density and extent of our Western forests are not accidental, but result because climatic and other conditions are the most favorable in the world for forest growth. In just the degree that they excel forests elsewhere is it easier to make them continue to do so.

\section{What We Are Doing With It}

On the other hand, forest fires in Montana, Idaho, Washington, Oregon and California destroy annually, on an average, timber which if used instead of destroyed would bring forty million dollars to their inhabitants. Idleness of burned and cut-over land represents a direct loss almost as great.

These are actual money losses to the community. So is the failure of revenue through the destruction of a tax resource. Equally important, and hardly less direct, is the injury to agricultural and industrial productiveness which depends upon a sustained supply of wond and water. 


\section{Does It PAY?}

Practically all this loss is unnecessary. Other countries have stopped the forest fire evil. Other countries have found a way to make forest land continue to grow forest. Consequently we can. It is clearly only a question of whether it is worth while. Let us consider this question, not only in its relation to posterity or to the lumberman, but from the standpoint of the arerage citizen of the West today. 


\title{
CHAPTER I
}

\section{FORESTRY AND THE PUBLIC}

\author{
Timber. Means Pay Checks
}

Forest wealth is community wealth. The public's interest in it is affected very little by the passage of timber lands into private ownership, for all the owner can get out of them is the stumpage value. The people get everything else. Our forests earn nothing except by being cut and shipped to the markets of the world. Of the price received for them nsually much less than a fifth is received by the owner. Nearly all goes to pay for labor and supplies here at home.

Even now, when the western lumber industry is insignificant compared to what it will be soon, it brings over \$125,000,000 a year into these five states. This immense revenue flows through every. artery of labor, commerce and agriculture; in the open farming countries as well as in the timbered districts. It is shared alike by laborer, farmer, merchant, artisan and professional man. It is their greatest source of income, for lumber is the chief product which, being sold elsewhere, actually brings in outside money.

That it is essential to the prosperity of every citizen to have this contribution to his livelihood continue requires no argument. From the manufacturing point of view alone, our forest resources are as important to everyone of us as to the lumberman, and in many ways more so, for if they are exhausted he can move or change his business, while the dependent industries cannot. But our welfare is at stake in a dozen other ways also. 


\section{- Our Interest as Consumers}

Every person who uses wood, whether to build, fence, burn, box his goods, or timber his mine, is directly interested in a cheap and plentiful supply of timber. Every acre burned, every cut-over acre lying idle, raises the price for him without furnishing any revenue with which to help pay it. Every acre saved from fire, every acre of young growth, lowers it for him and puts money in circulation besides.

Similarly, the cost to the consumer of most articles of every day necessity is directly affected by the connection of forest material with their production. Wood and water are almost as essential to mining as ore, hence influence the price of metals. In the form of fuel, buildings, or boxes, if not as an actual constituent of the product itself, wood supply bears a like relation to almost every industry.

Every reduction of the lumber traffic which helps support our railroads, or of their supply of poles, ties and car material, tends to raise the cost of our groceries and other railtransported commodities.

\section{School LANDS}

Most of our western states have immense areas of forested grant lands, the sale of timber from which supports the public schools and other state institutions. Destruction of this asset is a direct blow to these institutions which ean be only partially met by increased taxation.

\section{The Farmer has the Most at Stake}

In the case of western agriculture, the relation to the forest is fundamental and inseparable. Enough has been said to show that because of its importance as a sustaining industry lumber manufacture is a prodigious factor in creating a market for farm products, also that the cost of all articles used by the farmer is cheapened by forest preservation. But back 
of this lies the all-important dependence of western agriculture upon irrigation. We must save the forests that store the waters.

Of particular significance to the farmer, too, is the tremendous importance of forests as a source of tax revenue to help support state and county government. The cost of government is growing as our population grows. Taxable property grows mainly in the cities. Elsewhere we confront the problem of diminishing timber to tax and consequent heavier and heavier burden on farm property. It will be a bad situation for the farmer if the timber is all destroyed and he has to pay all the taxes, as well as a higher price for his buildings, fences and fruit boxes: Every acre of timber burned or wasted hastens this day.

The conservation thus suggested does not mean non-use of ripe timber, but does mean protecting it from useless waste and destruction, and replacing it by reforestation when it is used.

\section{Conditions of Life the Real Issue Involved}

Lack of space forbids recounting many other ways in which the forest question touches the average citizen. It enters into our prospects of development, our investment values and our insurance rates. Like the keystone of an arch, or the link of a chain, forests cannot be destroyed without the collapse of the entire fabric. Their preservation is not primarily a property question, but a principle of public economy, dealing with one of the elements of human existence and progress. Failure to treat it as such means harder conditions of life, a handicap of industry; not only for our children, but for us as well.

It all sums up to this: On every acre of western forest destroyed by fire, or that fails to grow where it might grow, we, the citizens of the West who are not lumbermen, bear fully eighty per cent of the direct loss and sustain serious further injury to our general safety and profit. 


\section{How We Throw Away Millions}

Notwithstanding the above facts, we allow $\$ 40,000,000$ which we and our families should share to vanish every year, leaving nothing more enduring than a pall of smoke from Canada to the Mexican line. The great area thus denuded uselessly, with that which produced public wealth through lumber manufacture, together having been capable of affording a community resource of $\$ 165,000,000$, are abandoned to lie idle and a menace to remaining timber. It is exactly as though the owner of a 165-acre orchard should destroy forty acres wantonly and also abandon the rest, unfenced, uneultivated and uncared for.

The one waste is as unnecessary as the other. Our Pacific coast forests owe their unparalleled productiveness to a peculiarly fortunate combination of climate and rapid growing species unknown elsewhere. Nowhere else is forest reproduction so swift and certain. Nowherc can it be secured with so little effort and expense. A little forethought in cutting methods and protection of the cut-over area from recurring fires, and an early second crop is assured. Saw timber can be grown in forty to seventy-five years; ties, mine timber and piles in less.

How We Might Make Immense Profit Instead.

It is reasonable to suppose that, although the quality may be inferior to that of the old forest removed now, timber scarcity will make a second cut in sixty years equally profitable per acre. Therefore, if the area denuded annually at present were encouraged to reforest and protected, it should at the end of that period again yield $\$ 165,000,000$ to the community. Each year's growth at present would be worth a sixtieth of that sum, or $\$ 2,750,000$. If given any chance to do so, the area deforested in only ten years would actually earn the people of our five western forest states $\$ 27,500,000$ a year. 
Almost nothing is being done to make it do so. As the result of the same popular neglect, this annual loss of nearly twenty-eight millions of dollars is added to that of forty millions caused by destruction of merchantable timber by fire, and the injury to tax revenue, water supply and countless dependent industries still remain to be reckoned. And to this sacrifice of wealth we add that of scores of human lives, incredible suffering, and the wiping out of homes and villages by forest fires.

\section{Plain Words For Our Present Policy}

Let us draw a parallel: If riot or invasion should sweep our Pacific coast states, killing unprotected settlers, plundering banks and treasuries of $\$ 40,000,000$ of the people's savings and business capital, and by destroying the producing power of commercial enterprise reduce the community's income by twenty-eight millions more, the catastrophe would startle the world.

If this stupendous disaster should threaten to recur the following year and every year thereafter indefinitely, annually taking $\$ 67,000,000$ from the earnings of the people, diminishing their invested wealth and paralyzing their industries, the situation would be unbearable. It would dominate the minds of men, women and children. All else would be forgotien in their preparation for defense.

Forest fire destruction is a danger in every way as real and immediate as riot or invasion, equally measurable in losses to us today and more far reaching in effect upon future prosperity. Although less sensational, it demands no less prompt action.

\section{The Action We Must Take}

The foregoing facts prove that our present forest policy is unprofitable to the state and its citizens. What, then, is the remedy?

At first thought it may seem that the responsibility for this 
lies with the man who controls the land, the timber owner and lumberman. He does have his part to play, which is discussed elsewhere in this booklet. But he will not, indeed cannot, do so until the rest of us play ours. The community must not only coöperate, but in some directions must act first, because from the beginning the Jumberman is governed by many conditions which are fixed by the people. It is for the people to make these conditions reasonably favorable so that he will have neither excuse nor incentive for failing to conform to them.

In this coöperation the people should not be expected to grant privileges which are not for their own advantage also. Nor should they hesitate to coöperate if it is to their adrantage, merely because it is also a help to the lumberman. It is natural that the public should disincline to assume any further burden to enrich the timber owner. Were this the sole object of forest protection it would be fair to leave it to him. But it is the height of bad economy to obstruct or refuse to help him in handling forest resources to our best advantage. Whether he gains or loses is merely incidental to us, but whether we gain or lose is of very great importance.

\section{First Step Is to Stop Forest Fires}

Obviously reduction of the forest fire hazard is the most urgent problem. Not only is fire the greatest destroyer of existing forests, but it also discourages investment in reforestation. The public has a right to expect the lumberman to adopt every safeguard against it in his operations. Nevertheless, the first step to encourage him in this is to reduce the appalling carelessness with fire in which the people of the West are the worst offenders in the world today.

Forest fires are almost always unnecessary. They usually result from a neglect of consideration for injury and distress to others which is not shown by the American people in any other connection. The traveler or resident in forest regions simply fails to realize that his own welfare and that of count- 
less others requires the same precaution not to let fire escape, and the same activity in extinguishing fires he discovers, that are accorded as a matter of course in cities and towns. In reality they are more important. A San Francisco can burn down and it is soon replaced. Insurance and capital come to the rescue, labor is employed, and business is resumed. But when the forest burns, industry dies and labor is driven away empty handed. It is a big price to pay for neglecting the slight effort required to prevent it.

- Fairly good fire laws are on our statute books. Presumably they were intended to prevent fires. Yet almost every forest community sees fire after fire set through ignorance, carelessness or purpose, and so far from punishing the offenders accords them every privilege of business and society. In cities, however insignificant the damage, arson leads to the penitentiary. A forest fire may destroy millions and the cause not even be investigated. If, aggravated by a particularly inexcusable case of malice or carelessness, some property holder (seldom the people) secures an arrest, acquittal is practically certain because the community considers the matter none of its business. Then the value of the fire law is at an end in that region. Certainly we cannot expect the timber owner to protect our forest interests until we ourselves respect and at least attempt to enforce our forest laws.

\section{Patrol Service Absolutely Essential}

But necessary as is better public sentiment, we must also have practical machinery for enforcing the laws and for stopping the fires that do start. Just as a city is safeguarded best by an organized fire department, so the forest can be protected effectively only by trained men who know the work. And the man who prevents the most fires is the man who is looking for them, not the man who goes after the fire is under way.

Theodore Roosevelt says: "I hold as first among the tasks before the states and the nation in their respective shares in 
forest conservation the organization of efficient fire patrols and the enactment of good fire laws on the part of the states."

The National Conservation Commission reports: "Each state within whose boundaries forest fires are working grave injury, and that means every forest state, must face the fact squarely that to keep down forest fires needs not merely a law upon the statute books, but an effective force of men actually on the ground to patrol against fire."

We all know that few disastrous fires start under conditions which prevent their control. Usually they spring from some of the many small, apparently innocent fires which burn unnoticed until wind and hot weather fan them into action. It is far cheaper to put them out in the incipient stage than to fight them later, perhaps unsuccessfully until after great damage has been done. And if fighting is necessary, it is of the highest importance to have it led by competent, experienced men. Moments count, and bad judgment is expensive.

Most western states already have laws regulating the use of fire for clearing during the dry season. To accomplish this with safety and without hardship requires fire wardens to issue permits and help with the burning if necessary.

Public knowledge that there is someone to enforce the law tends to restrain the dangerous class. Still more useful is the service of fire wardens in agitating the fire question and keeping before forest residents the advantage of their coöperation.

\section{Co-operation With Private Owners Desirable}

In fire patrol, especially, the state and the lumberman must work together. It is reasonable that the timber owner should contribute to the protection of his property. He also has peculiar facilities for getting the work done well and cheaply. As a rule he is willing to do his part. In 1910 the Washington Forest Fire Association and other timber owners in that state paid out $\$ 300,000$ for patrol and other fire work. The Coeur d'Alene, Clearwater, Potlatch and Pend d'Oreille Timber Protective associations spent over $\$ 200,000$ in Idaho. 
Oregon timbermen spent approximately $\$ 130,000$. Figures are not available for Montana and California, but probably the same proportion holds.

Thorough support by the state is necessary to make private work effective. The men employed must have official authority to enforce the 1aw. The dangerous element does not respect a movement which nominally represents only the property owner. The people in general do not aid it as much as they do one in which they also share. Therefore, it is necessary to have state facilities for coöperating in the organization, authorization and supervision of all forest patrols.

\section{Liberal Appropriation a Good Investment}

But to stop here is like attempting to protect a city from fire merely by giving its factory owners the right to maintain watchmen. We want to provide for the greatest possible advantage to the people through the timber owner's desire to protect his own property, but any forest policy which ends with this is hopelessly weak. We cannot afford to leave any matter of public welfare wholly to the wisdom and philanthropy of private enterprise. If we expect our paramount interest in forest and water resources to be looked out for properly, we must pay for it just as we do for all other protection we get through organized government. Nor should we forget that the timber owner helps us again in this, for he pays taxes as well as the cost of his private patrol.

There are also many regions where timber values do not warrant patrol, but where the safety of other property, and of life, demand both patrol and fire fighting. Here the state owes its citizens protection. Moreover, one of the węakest points in our present system everywhere is lack of police authority to apprehend violators of the fire laws. The private warden cannot successfully arrest or prosecute offenders, and everybody knows it. Most fires start through violation of law. To prevent them the law must be respected, and to ac- 
complish this there must be state officers who can and will apprehend offenders without fear or favor.

Any western state can well afford to spend $\$ 100,000$ a year for a forest fire service which will prevent a loss of fifty times that sum. The cost is imperceptible by the citizen, his benefit immediate. Forest protection is the cheapest form of prosperity insurance a timbered state can buy.

\section{Reforestation}

Although it does not pay to burn up our forests, it does pay to use them. The faster we can replace them with new ones, the quicker this profit can be made with safety. Forest land is community capital. To let it lie idle is as wasteful as destruction. And we must also remember that the day is coming when our forested streams must do a hundred times their present duty, and when the lumber consumer's question may not be "What must I pay for a board?" but "Can I get a board at all ?" We must have new forests coming as the old ones go.

The Federal Government is practicing forestry in the lands controlled by the Forest Service. Why should the states not to the same thing with their school and tax deed lands? Intelligent care of timbered school land, selling the timber only under regulations which will insure reforestation, would realize as much today and in the long run pay a thousand per cent in dividends for the education of our children and our children's children.

Further than this, there should be legislation to permit the state to solidify its forest lands by exchange, when advisable, and to authorize the purchase of cut-over lands. The eventual profit in this is certain to be great, and nothing will do more to interest the public and private owners in reforestation. It is the history of all countries that forests are peculiarly profitable state property, especially when, as is the case with 11s, it can be acquired clieaply. It is a sound and well-proved policy that it is well for the state to own lands which are 
not adapted for permanent individual development. Forest lands constitute the ideal class, not only because the state is in the best position to keep up their usefulness to the community, but also because they will earn perpetual revenue far greater than they could bring through taxation. They will pay back the cost and interest, become increasingly valuable, and still pay dividends.

It is even more important that reforestation be secured on private lands, because their area is greater than that owned by state and government. With the encouragement which could be given the owner without any undeserved concession, conditions would warrant him in securing it. We have reached that stage in our development. The exhaustion of timber in the country at large, the increase of consumption, and our peculiar natural advantages, have combined to promise adequate financial return. And the lumberman does not want to go out of business unless he has to.

\section{Obstacles to Private Effort}

To insure a second crop the lumberman has to lose more or less money when he cuts the first. His methods must be more expensive and he must forego present profits on trees he leaves. If he plants, the outlay is considerable. But let us suppose he is willing to do all this, not because he is a philanthropist but because he wants more trees to run his mill some day.

It is a comparatively simple matter to get his second crop started. American forestry has solved this problem fairly well. It is also easy to calculate in most cases, beginning with the sale value of cut-over land, using safe estimate of ${ }^{2}$ the next yield and the time required to mature it, and setting a conservative future stumpage value, that growing timber ought to be a profitable investment. If that were all, we could leave the lumberman alone and count on him to perpetuate our forests because it will pay him to do so.

But the whole calculation, consequently the public's inter- 
est as well as his, is upset by two factors-the danger that his investment will burn up and the practical certainty that taxes will eat up all profit before the harvest. If he figures on fire protection at his own expense against the hazard as it now exists, and the tax burden on cut-over land which is indicated at present, his engagement in forest growing will be negligible from the point of view of public welfare. In some cases he may hold the land awhile, in few can he afford to protect it, in still fewer is he justified in actually doing anything to insure reforestation.

If a man proposes to build a factory or railroad in a community the inhabitants usually encourage him. They do not refuse him fire protection in the first place and then, if his plant burns down, threaten to burn it again and keep up full taxation on the vacant land. They offer every fair inducement to get the industry and keep it flourishing. They expeet it to pay its just share of taxation, but want it to continue to do so as long as possible.

\section{Tax New Crop When Harvested}

It has been shown that the first obstacle to reforestation of private land ean be removed only by supporting a fire patrol and creating public sentiment which will reduce the number of fires. The seeond is even more wholly in the hands of the people, for by the system of taxation they impose they decide whether it shall continue an earning power and a tax source forever or be abandoned to become a desert; non-producing, non-taxable, and a menace to stream-flow. Whether its owner has made money on the original crop has no bearing on the result, nor has his being rich or poor, resident or alien. Cutover land presents a distinct problem to him. He will and should pay a full tax on its earning power, which will be demonstrated when he successfully brings another erop to maturity. But he cannot earry an investment for fifty years or more withont return, with a risk of total loss by fire up to 
the last moment, at a cost which would bring him better profit in some other business.

These facts are recognized by all students of forestry. The following authorities hold no brief for the lumberman. They approached the subject solely from the side of the people:

Theodore Roosevelt: "Second only to good fire laws is the enactment of tax laws which will permit the perpetuation of existing forests by use."

National Conservation Commission: "Present tax laws prevent reforestation of cut-over land and the perpetuation of existing forests by use. An annual tax upon the land itself, exclusive of the timber, and a tax upon the timber when cut is well adapted to actual conditions of forest investment and is practicable and certain. It would insure a permanent revenue from the forest in the aggregate far greater than is now collected, and yet be less burdensome upon the state and upon the owner. It is better from every side that forest land should yield a moderate tax permanently than that it should yield an excessive revenue temporarily, and then cease to yield at all."

H. S. Graves, Chief Forester for the U. S. : "Private owners do not practice forestry for one or more of three reasons: 1 . The risk of fire. 2. Burdensome taxation. 3. Low prices of products."

Professor Fairchild, tax expert, Yale University: "Forestry must come some time, and its early coming is a thing greatly to be desired. We can hardly hope to see the general practice of forestry as long as the present methods of taxation continue. With regard to its effect on revenue, there is little to be feared from the tax on yield. It is equitable and certain. If a tax at once equitable and dependable is guaranteed, the business of forestry will not need to ask special favors." 


\section{Crying Need For Definite State Policy}

To accomplish these reforms will take law-making and lawenforeing. However well we study existing conditions and legislate upon the premises they furnish, success depends upon competent application of the laws and their improvement as conditions change. It is a bitter reproof to us of the West that Eastern states, with forest and water resources insignificant compared to ours, have gone so much farther in securing the services of trained men to study these questions and to guard both private and public interests. The very first step should be to get competent trained state foresters who will devise wise measures, protect us from unwise ones, and edueate lumbermen and public alike to the common need of action. We pay cheerfully for every other kind of public service, for geologists, veterinarians, insurance commissioners, barber examiners, and what not. But the two things we must have-wood and water-we leave pretty much to take care of themselves, and they aren't doing it and never will.

The essentials of a wise state forest policy, based not on theory but on successful experience elsewhere, are as cheap as they are simple. Where tried they have never been abandoned. If they pay elsewhere, can we afford not to try? Following is the framework of a code demanded by the situation in every Western state. Some already approach it, but none goes far enough:

\section{Essentials of Fffective State Forest Code}

1. A State Board of Forestry selected with the single view of insuring the most competent expert judgment on the matters with which it deals. In other words, the board should not be political, but appointment by the Governor should be restricted to responsible representatives nominated by the interests most familiar with forest management, such as state forest schools, lumbermen's associations, forest fire associa- 
tions, conservation associations and the resident Federal forest service.

2. A trained state forester, wholly independent of politics. Executive ability and practical forest knowledge should be considered essential, also scientific training. He should have one or more assistants of his own appointing.

3. A liberally supported forest fire service, in which the state forester has ample latitude in coöperation, financial and otherwise, with all other agencies in the same work.

4. A systematic study of forest conditions to afford basis - of both intelligent administration and desirable further legislation.

5. A system for active general popular education, with specific advice to individuals in proper forest management.

6. Application of forestry principles to the management of state-owned forest lands and the purchase of cut or burned over land better suited for state than for private forestry. This is to furnish educative examples of conservative management as well as to maintain state revenue and proper forest conditions.

7. Improvement and strict enforcement of laws against fire and trespass, with penalty for neglect to enforce them by any officer who is paid to do so.

8. Encouragement of reforestation by assessing deforested land annually on land value only, deferring taxation of forest growth until its cutting furnishes income with which to meet the tax.

9. Thorough study of the subject of taxing standing timber, to the end of securing a system which, by insuring a fair revenue without enforcing bad forest management, will result in the greatest community good.

\section{Do IT Now}

You, the average citizen of the West, are responsible for the present situation and for its remedy. Merely to agree that it is unfortunate, and virtuously to condemn firebugs, careless 
lumbermen and indifferent legislators, does not relieve you of the responsibility. Neither will it protect you from the consequences. On the other hand, the firebug will not fire if he knows it will not be tolerated. The lumberman will adopt protective methods if you encourage him. The legislator is glad to help in any way his constituents suggest. They are all only waiting for a word from you, whose welfare is really at stake and from whom the word should come.

If any other principle of public safety-say suppression of fraud, burglary or murder-was being so generally ignored, what would you do? Would you not look up the laws of the state and find a way of letting everyone connected with their enforcement know that you expected them to be enforced? If you found lays or appropriations inadequate, would you not see to it that every representative in the legislature knew his constituents demanded improvement?

The legislator or public official is anxious to comply with the people's wishes, but he must know what the people want. It is essential to let him know that you want a progressive and Jibcrally supported state policy that will save our immensc forest wealth from necdless destruction. 


\section{CHAPTER II}

\section{FORESTRY AND THE LUMBERMAN}

\section{The Underlying Principles}

The lumber industry is undergoing a process of reorganization which reaches to its very foundations. It is so deepseated as to be almost imperceptible from outward evidence, but is of profound-significance to the owner of timber land and to the public.

Hitherto lumbering in the United States has consisted chiefly of manufacturing and selling. The raw material has occupied no consistent place in the equation. The value it has had in fixing the price of the finished product has been merely in its relation to transportation. Intrinsically it has been accorded no value. This situation continued just as long as there was practically free Government timber to be had by opening it up.

It continues now only relatively, however. Transportation must always remain a great factor; the timber owner is still obliged temporarily to meet his obligations by means determined under the old basis. Nevertheless, the moment it became impossible to get timber to manufacture without assuming the costs of producing, such as fire protection, taxation and interest, began an era of inevitable natural regulation. From that time on timber began to assume a value which, although affected by transportation facilities, must. cventually be fixed chiefly by the cost of growing other timber to compete with it. 


\section{Timber Is Worth the Cost of Growing It}

In other words, the value of anything is what it costs to produce it, whether it is a tree or a box of apples. That we found our timber orchard growing when we came to this country does not change this law. It was suspended temporarily while any individual could profit by the growth produced without cost, but began to operate again when he could no longer do so. We are now in a transition period of adjustment. The important thing to remember is that this will not continue until the entire output has actually borne the full cost of production, for before then investments in standing timber will have been regulated by the same influence.

It is true that at present the cost of lumber to the consumer is not fixed absolutely even by the cost of manufacturing and selling it, and that on the contrary it fluctuates greatly with the willingness of the consumer to buy. But this, except within limits, is not a sound working out of the law of supply and demand. It is an ineident to the unsound basis of production which still prevails. So long as a very large portion of our standing timber has not cost the owner much in either price, protection, taxes and interest, some of it will be put on the market at a low price in order to carry a milling business through a depressed period, to realize money, or for other exigency reasons. So may a wheat grower lose money on one or two years' crops. But if in the long run the world refuses to pay for wheat what it costs to grow it, wheat will not be grown. The real question is whether or not the world needs forests enough to pay for them.

\section{Demand Will Continue}

It is evident, from the history of older countries, that it does. While consumption per capita will undoubtedly decrease, population is growing. Substitution will be necessary, but will not supplant wood for a multitude of purposes. Much has been said about the use of steel, encrete and like ma- 
terials in building. The building trades only use 60 per cent of our lumber today, without considering fuel. It is unlikely that the reduction of this percentage. will very much more than offset the growth in volume of the reduced percentage due to increased population. Fifty years ago there was scarcely a lumber user west of the Mississippi river. We know the settlements, mines, railroads and cities that have developed since to use lumber. It is a poor Westerner who doubts that the next fifty years will see a far greater development. And the Panama Canal is coming, with the certain result of making our fast-producing forests able to compete successfully with Eastern and European forest crops grown with less natural advantage.

Moreover, we now use three and a half times as much wood a year as our forests produce. Consequently the demand might even fall off three and a half times and still consume the product. And the forest producing area diminishes constantly. Little as we now consider the possibilities of food famine, history shows that nations rapidly increase to the limit of their agricultural production or beyond, and we must reckon not only on our own increase but also upon immigration from, and export to, nations whose pressure upon their production exceeds ours. It is certain that land now considered too remote, rough and poor for agriculture will be put to that use. We know that other countries do not to any considerable extent devote land to forest that will grow food crops at all well.

\section{Adjustment Only Question of Time}

Consequently it is safe to assume that within reasonable limits the consumer will be glad to pay the cost of growing timber when he is obliged to do so. It is also to be expected that the community will desire to maintain a resource which employs labor, pays taxes, and conserves stream flow. Therefore, the price of lumber will be governed, as the price of every staple commodity is governed, by a cost of production 
including reasonable profit by those engaged in the several stages of the process. That it will include the growing of new timber on a sound, profitable basis is proved by the history of other countries which have undergone the same regulation. This, after all, is the strongest argument with which to answer the skeptic who, on premises and judgment of his own, doubts the abore conclusions. We need not claim greater prophetic ability, but have only to make the undeniable assertion that hindsight is better than foresight. Nothing demonstrates economic laws so irrefutably as experience.

Less than 29 per cent of the land area of the United States is occupied by forests today, including swamps, burns and much land which will be deroted to agriculture. Germany, where great economy of material is practiced, where wooden buildings are far fewer, where, indeed, the per capita consumption is only a seventh of ours, keeps 26 per cent of her land area under the most expensive forest management and finds the profit constantly increasing. She is increasing her production and importing heavily from countries where lumber is cheap, like the United States, yet the net returns per acre from the forests of Baden rose from $\$ 2.38$ in 1880 to $\$ 5.08$ in 1902 . This was due largely, of course, to improvement of management. In France lands which only fifty years ago could not be sold for $\$ 4$ an aere now bring an annual revenue of $\$ 3$. In 1903 the town forest of Winterthur, Switzerland, brought net receipts of $\$ 11.69$ an acre. These are fair examples in countries where the influence tending toward less use of wood have been working for a very long time. They show such influences do not result in refusal to pay the cost of growing all the wood that can be grown. Wood consumption in European countries is increasing at a rate of from $11 \frac{2}{2}$ to 2 per cent a year. In other words, the consumers are actually willing to pay for more wood than they have found necessary, and are warranting the growers in adopting still more expensive methods to increase the output. Nor has forest growing. proved to he possible only by the State or Government. In Germany 46.5 per cent of the forest area 
is owned privately, in Austria 61 per cent, in France 65 per cent, in Norway 70 per cent. While it is true that the European private owner has better tax and fire conditions, it must also be remembered that the value of the land on which he makes the growing crop yield a good dividend is about ten times as high as it now is in the United States.

The prospective grower of new timber in the American West can expect equal profit here at some time. His chief concern is whether its foreshadowing influences are sufficiently strong at present. 'To determine this he must consider' the probable attitude of the public and of the lumbermen themselves.

\section{What It Means to the Consumer}

To the consumer the principles previously outlined mean that the price of lumber will rise somewhat. Indeed, he must expect that, regardless of the production factor, for the timber owner cannot pay taxes, prevent fire, and keep his money tied up, all for a considerable period, and still sell the material as cheap as he could before these expenses accrued. It also means that if the consumer fails to recognize and concede these principles it will be at his own sacrifice. Too low prices now merely mean too high prices in the early future, for they will not permit protection, economy or reforestation. He must eventually, and not far hence, pay the total cost of production. It is urgently to his interest not to add to this by preventing production and thus permitting the owner of the timber already produced to speculate on the approaching shortage.

The danger of this can be illustrated by a comparison. Suppose three-quarters of the apple growers of the country, either through ignorance of the principles of their industry or through shortage of money with which to pay their debts, should be forced for a considerable period to accept a price for. their crop so low that after paying current bills they were obliged to neglect their orchards absolutely, without plow- 
ing, feneing or spraying. Suppose further that the public should also destroy a large portion of the orchards, as the forests are by fire, and also overtax the land so as to complete the discouragement. Clearly apples would immediately go up. A few growers would doubtless eseape absolute destruction and these, as long as their orchards lasted, would demand a price overbalaneing many times the saving the consumer made temporarily while he was destroying the industry. Everyone concerned would be worse off than if prices had remained just high enough to maintain an adequate supply.

It is improbable, however, that the consumer will ever voluntarily pay more than he has to, even if it is to his ultimate advantage. The most that ean be hoped is that as the public at large comes to understand the situation, it will not support him in the claim that injustice is being done by the rises he is forced to meet as conditions adjust themselves. His reluctance will retard, but not stop, the progress of good forest management.

\section{States Will Take a Hand}

On the other hand, it is reasonable to suppose that the people of the timber-producing states will gradually come to see that their interest, as well as that of the lumberman, is to be furthered by placing the industry on a sound basis. Selling more lumber than they consume, they will not rejoice over low prices any more than a wheat state does over the fall of wheat beeause it uses some flour, but they will be equally unable to exert much stiffening influence on the price. Consequently they will probably attempt to sustain the industry by increasing production. But in this attempt they will consider immediate community advantage first, future community advantage next, and the lumberman's advantage only as it is incidental. And such measures as they endorse they are likely to enforee by law.

We see, then, that two forees are making for the better 
handling of our forest resources; the economic necessity of the public and the business advantage of the owner. Both demand the maximum production. Obviously, since their aims are identical, each has to gain from earnest coöperation. Neither can succeed alone, for the owner cannot go far against hostile laws or sentiment, and the public cannot accomplish half as much by compulsion as by encouraging the owner. But the great danger to each lies in mutual distrust, which defers the establishment of effective coöperation.

\section{Lumberman Must Show Good Faith}

The primary and all-important moral which all this points out to the lumberman is that his position under coming conditions will be largely what he makes it by his own attitude. With the rapidity with which he gets into a position where his voice is listened to as unselfish and authoritative on the conservation subject, will his influence on the new conditions be measured. Therefore, he must study the subject. He must be able to support good laws and oppose bad laws with facts and arguments which will stand scrutiny. Above all, he must show faith by practicing what he preaches so far as he is able. He must show conclusively the injustice of the public suspicion from which he suffers.

Conservative forest management has three essentials: Protection, utilization and reproduction. The last particularly depends on the first. 'The timber owner cannot protect adequately alone. Before he can expect much public help, however, he must show his willingness to do his share, for the state will not assume the whole burden. The progressive members of the industry have shown it already, and the result is evident in the commencement of the states to help. Their help will increase in the proportion that private effort spreads.

Presumably it will be the same with reforestation. With the fire hazard lessened there will remain the obstacle of overtaxation on property returning no income with which to meet it. The public will doubtless soon see that this is bad for the 
community, but will hesitate to forego present revenue in order to reap greater future revenue until convinced that the owner will actually reforest if given the chance. Even if no actual desire to take advantage is ascribed, there may be fear that he will make no active effort to start and protect the second crop, but will merely continue the course of least expense in the hope that a new forest will establish itself, with little to lose if it fails. Before he will receive the encouragement he deserves, he must prove his good faith. The surest way to do this is to begin actual work now, where he ean without certainty of failure. Unfortunately, this is often impossible, but he can at least" study and experiment so he can argue convincingly that mutual success will follow reasonable encouragement.

\section{Circumstances Determine Profit}

Let us assume, then, that it is best for the lumberman to start the practice of forestry for the purpose of strengthening his position and getting the most favorable conditions possible for its general adoption and continuance. How mueh does he depend upon success in this? Obviously, early public favor will hasten and add to the security of forest growing as a husiness, but is it absolutely essential? Do existing conditions and ineritable future conditions, regardless of public intelligence, furnish premises upon which we can calculate certain profit in some degree?

This depends upon the cireumstances of the individual investor. Without an expectation of more favorable fire and tax influences, reforestation cannot be universally recommended as a business proposition. Nany timber owners are not warranted in undertaking it. Not enough are warranted in doing so to insure the future timber supply upon which public welfare depends. Tevertheless, there are conditions under which it is a good investment. It is even probable that for those who are well situated, the very chstacles which deter others will be advantageous through reducing competition. 
This fact is of peculiar significance to the public, for if the latter fails to stimulate reforestation generally it will play directly into the hands of the few who are independent of encouragement.

It is customary, in speculating upon the profits of a second timber crop, to attempt to reduce it to a financial calculation based upon estimated yield, estimated future values and estimated carrying charges. These considerations are important, but their importance is largely in proportion to the financial weakness of the prospective timber grower. We revert again to the practical certainty that unless reforestation is general, the exhaustion of virgin timber will be followed by a shortage, and that the man who has a second crop at that time can obtain a price which will reimburse his carrying charges be they high or low. The cost of overcoming present obstacles will be shifted to the consumer. The possibility of such an investment is determined largely by ability to maintain a protective system with economy and to bear the expense of this and of heavy taxation during the period of no return.

In short, the weakness of the ordinary financial calculation upon existing conditions is that it attempts to estimate future stumpage values without knowleage of the true factor which will determine them. This factor is not the probable rise of existing stumpage while it continues to exist, but is the extert of the new-grown supply which will follow it provided existing conditions remain unchanged. It is inconsistent to figure the cost upon almost prohibitive present conditions without also recognizing that such conditions, if continued, will completely change the influences which now determine the market.

\section{Who Can Afrord to Reforest Now}

On the other hand, timber owners have by no means equal opportunity to take advantage of this fact. The productive capacity of their land varies, their taxes vary, the extent and location of their holdings affects the expense of protection against fire, and they have not the same facilities for financ- 
ing a long term investment. It is the balance of these factors that determine their opportunity. Assuming rate of timber growth to be equal, present fire and tax conditions classify them in relative advantage about as follows:

1. Owners of large holdings of virgin timber who can meet carrying charges by occasional sales at a profit over their purchase price, but will not sell much more than is necessary because all they can afford to hold is advancing in value. Such owners have more or less land deforested by fire or their own milling operations, and will incline to sell only stumpage without land. This land is not easily realized upon at present, and for the speculative reason stated, they will continue in business long enough to grow a new crop on it. The larger their holdings, the greater the certainty of this and the cheaper, relatively, the cost of protection. Moreover, concerns dealing with large and long term investments can consider a lower interest rate.

2. Owners with less facility for making an actual profit through growing timber, but desiring to maintain a milling business. Even if the cost of growing approaches or equals the value of the crop, they will be able to count on continued manufacturing profit.

(Both of the above classes face a possibility of so heary a tax on their virgin timber in some instances that they will be obliged to eut it and go out of business. This is unlikely to occur generally, however, for tax reform is almost inevitable, and it would have a compensatory effect of enhancing the value of the second crop.)

3. Owners whose holdings are not large enough to keep them in business until a second crop matures but are advantageously located. Second growth need not be mature to have a value. As the present supply diminishes, available coming supply will gain a high expectation value which can be realized upon. The profit it offers will be largely determined by its proximity to market and especially by its proximity to established mills which see their own supply running short and have failed, through inability or lack of fore- 
sight, to engage in reforestation themselves. It will also be affected by tax and fire charges, and the latter, especially, will be largely a matter of location.

4. The owner with no peculiar advantages, who can only set the general certainty of a market for second growth against his ability to carry a costly and uncertain investment for an indeterminate time.

Of course a first consideration in most cases is the comparative profits of other possible investments or, in other words, the exact interest demanded as satisfactory. Individuals are in by no means the same position in this respect by either inclination, opportunity or talent. Where one might be safer with his money in timber, another could make more by manufacturing. Generally speaking, however, conservative judgment leads to the conclusion that the present attitude of the public warrants the first of the above four classes of owners in undertaking inexpensive reforestation where the land has little sale value for other purposes and where the growth and fire factors are reasonably favorable. The second class can also undertake it to advantage on much the same basis, but having less capacity for meeting the carrying charge, requires still more favorable conditions. The third class must have the maximum advantage of every kind.' It must calculate closely on the factors of cost and profit indicated by present conditions. In most cases the risk will be too great for prudence, and in nearly all financial ability will be lacking. The fourth class cannot even consider it until the public's attitude changes.

\section{Better Day For All Is Near}

On the other hand, it is reasonable to suppose that publicly-imposed obstacles will decrease. It will become apparent that their persistence is bad economy. Fires will grow fewer and the state will aid in patrol. Reforestation in itself is a method of fire prevention when it places a green young growth on a fire-inviting tract of sun-dried litter and weeds. Taxa- 
tion will be deferred. As the country develops interest rates will fall, making it easier to carry forest investments and harder to gain more through other investments. The state itself will engage more and more in forestry, with the result of making its principles understood and endorsed. Stumpage values will increase. Immature timber will have a sale value, lessening the term of investment. Gradually the business will get on a sound production basis, better for the consumer, better for the state supported by a forest income, and more profitable for the grower. Instead of capitalizing bad management and the sacrifice of the consumer, which in effect it does now by forcing the prospective grower to calculate on covering unnecessary cost in the price received, it will capitalize the earning power of forest land.

While final adjustment on this basis is still in the future, it is by no means entirely dependent upon popular foresight. The process is going on constantly, whether we know it or not. 'The sun is still behind the horizon, but the day is sure. Many Western timber owners are still in too dim a light to make their footsteps certain; others have a high vantage ground where dawn already lights the path. 


\section{CHAPTER III}

\section{FORESTRY AND THE FOREST}

\section{Elementary Principles of Forest Growth}

Whether the lumberman's judgment of economic influences leads him to be optimistic or otherwise as to the profit of forestry in general, he is most interested in the particular forest with which he has to deal. He can neither accept nor dismiss the proposition intelligently, much less put his ideas into actual practice, without knowing something of the capability of his land to respond to his effort." "What methods are best, what will they cost, and what will be the result?" are questions which arise at the rery outset. They lead at once into the domain of technical forestry.

With us forestry has not been practiced long enough to furnish demonstrated examples with which to answer such questions. We can, however, profit by experience gained elsewhere, for the laws which govern tree life are as universal as those which govern the life of men and animals. In dealing with new species and new environments we have no great difficulty in judging their future from their past, which lies written plainly for those who care to study it.

While to some extent trees require elements obtainable only from the soil, they are more independent in this respect than most other forms of vegetation. Soil influences forest trees mainly by its physical character, especially as this determines the moisture contents. Very little nourishment is actually taken out of the soil for, as someone has said, wood is nothing 
but air solidified by sunshine. A tree's immense and complicated foliage system is the laboratory with which it effects this transformation.

Since air exists everywhere and the chemical quality of the soil is comparatively unimportant, the requirements of different species for light, heat and moisture are what mainly determine their distribution and habits of growth. And since heat and moisture are largely climatic factors and fairly uniform in given loealities, it follows that the demand of a species upon light may practically fix its habits and possibilities in those localities. The very great variance of species in light requirement accounts to a large extent for the composition of most primeval forests. It is of peculiar importance in the management of forests by man because he cannot control it as he may be able to control some of the other agencies which affected the primeval forest, such as fire or seed supply.

\section{Selection Forests}

It would be unprofitable to discuss here all the many methods of forest management which have proved to be best, technically, for given species and combinations of species. Where market and transportation facilities are highly favorable, as in Europe, the timber owner ean adopt the method which will bring the best results, but here he has no such choice. He ean but bear in mind certain fundamental principles, uniformly applicable to large areas for considerable periods of time. Roughly, however, our Western forests ean be classified by their adaptability to the two directly opposite systems, known as clean cutting and selection cutting, of which almost all methods are modifications.

A selection forest is one in which all ages of trees exist, from seedling to maturity. It is the natural growth of species which are tolerant of shade. In a natural state, undisturbed by cutting, it maintains much the same aspect continuously, for as the oldest trees die, their place is taken by younger ones. Obviously such a forest must be composed of species, 
whether one or several, which can grow beneath its own shade. The understories of varying ages are as dense as their light requirements and the density of the overwood permit.

The common hardwood forests of the East illustrate one type of the natural selection forest. On the Pacific slope an example is afforded by hemlock, either practically pure or mixed with white fir, but probably the most typical is the ordinary Western yellow pine under certain conditions. At its best this tree composes a forest so dense that all young growth is shaded out, but everyone is familiar with the frequent opener stand containing all ages. The younger trees are often called blackjack.

\section{Even-Aged Forests}

On the other hand, trees extremely intolerant of shade occur only in what the forester calls even-aged forests. Being unable to start in the darkness of an existing stand of any considerable density, they must seize opportunities to recover openings. The Douglas fir of the Northwest, more commonly called red or yellow fir, is an excellent illustration. In the interior states this species reproduces under corer to some extent, because there is a stronger light average throughout the year and because the stand is not so dense. In the typical Douglas fir forests of Oregon and Washington, discussed in this booklet, it never does so. While hemlock, cedar and white fir undergrowth may be abundant, Douglas fir seedlings are seldom seen except in burns, slashings, roads, or open spots in the woods. And the fir trees composing the dominant stand are of nearly the same age.

How, then, did this even-aged fir forest begin? Close scrutiny will practically always find the answer in fragments of charred wood. Long ago another similar forest occupied the ground until lightning or an Indian's fire started a new cycle. Possibly recurring burns swept the area many times before wind-blown seeds began to start advance groups of fir, which, when fifteen or twenty years old, themselves fruited. 
and filled the blanks between them. Perhaps destruction was not so complete and surviving trees made the process a swifter one. Exeept in the very oldest forests, where remains of the original stand have entirely rotted away, the history in either case may be read in ancient snags and fallen logs.

Suppose, however, that fire had not come to aid the fir in perpetuating itself? This, too, we can answer from the signs today. Every Northwestern woodsman knows tracts of varying size (usually small because fire has been almost universal) covered with big old hemlock, white fir and cedar, with here and there a dying giant fir, perhaps, but mainly showing fir occupancy only by rotting stumps and logs. No sign of fire is seen. When this fir forest was approaching middle age, the shade bearing species began to appear beneath it. As the firs began to crowd themselves out, the later comers shot up with the increased light and filled the open places. At last the even-aged fir forest was eompletely transformed into a seleetion forest of other trees, which will remain until some accident again gives fir a chance if any survives near enough to reach the spot with seed.

Douglas fir is not the only Western tree which usually grows in even-aged stands. Lodgepole pine has the same habit, often supplanting yellow pine after fire or logging. Western white pine is perhaps more tolerant than Douglas fir, hence more likely to hold its own without artificial aid, but is also more certain to compete successfully if it has such aid. The same is true of tamarack.

\section{Nature as a Model.}

We thus see that if economic reasons suggest it, we may use the selection system as a basis for artificially managing the shade bearing species such as hemloek, white fir, cedar, spruce, and even Western yellow pine. We may eut the largest and oldest trees and still have a well started second crop. If there is not much young growth to leave, even a little is valuable. It may be deeidedly best to leave medium 
sized trees, which otherwise we would cut, because they are still growing rapidly.

On the other hand, we see that this, method would not be of any advantage at all in insuring a second crop of Douglas fir, for there is no young growth of this species to protect. The small and medium sized trees, instead of being immature, are merely stunted specimens of the same age as their larger brothers and unlikely to gain in size if left. Selection cutting here would save for future use only such understory of shadebearing species as may exist. Unless this is an object, the best plan is to cut clean and get all-we can. If we leave any fir at all it is for the purpose of reseeding, not to secure better utilization of the trees themselves, and whether we do so depends, theoretically at least, upon whether it is better than artificial seeding or planting. In short, selection cutting harvests the ripest trees of a perpetual forest, while clean cutting destroys the forest in order to start an entirely new and more rapid growing one.

Clean cutting is therefore necessary as well as natural in dealing with intolerant trees. But it does not follow that the selection system, although natural to tolerant species, is the only one adaptable to them. While the one class demands light, the other does not demand shade. It is merely capable of enduring it. Indeed, except for the greater susceptibility of some species to extreme heat and dryness when very young, as a rule shade bearing trees grow much better if they do have ample light supply. Consequently clean cutting may be the best system for these also under certain economic conditions.

Besides its influence upon the occurrence of species in the forest, light practically governs the physical form of the individual tree. If grown in an opening and not artificially pruned, a tree will have a conical trunk and living branches almost down to the ground. The denser and consequently darker the forest, the more cylindrical the trunk, the smaller the crown of branches and the greater the clear length. The individual tree has no object in assuming a desirable com- 
mercial form and does so only when deprived of side light by numerous neighbors. Then it sacrifices diameter growth to height growth in reaching for the top light necessary for its life. At the same time the lower branches are killed by shade and drop off, the scars being healed and eventually buried. The pin knots near the center of a big clear log are the remains of branches which when living were at the top of the young tree.

This is why, if it is to produce good timber, any forest must be dense enough to cover the ground throughout the early part of its life at least. When we see an excellent clear stand of mature Douglas fir, for example, we may know that it consists of the comparatively few survivors of a close sapling growth in which the weak were gradnally killed ont after serving their office of pruning and forcing the vigorous. Had only the trees we now see been on the ground they would be worthless except for firewood. For the same reason artificial forest planting must be thick, although the fillers or nurse trees may be of inferior species if not of so rapid growth as to gain the mastery.

Nature teaches many lessons which we must recognize in artificial management or fail, but she is no more the best grower of forest crops than she is of agricultural crops. We have to study natural methods of forest perpetuation to see how they may be improved npon as much as to adopt them as models. As a rule the virgin forest is exceedingly wasteful of ground. 'The possibilities under intelligent eare are not indieated by nature's average, but by her aceidental best, and usually they far exceed even this. A fair comparison is that of seientific farming with unsystematic gleaning from wild and untended fields. The foregoing general principles of forest growth have been purposely outlined very briefly so as to serve as a mere introduction to their application or modification in eonerete cases. 


\section{MANAGEMENT OF SPECIFIC TYPES}

\section{Douglas Fir (Pseudotsüga taxifolia)}

Compared with most important commercial trees, the Northwestern Douglas fir is remarkably easy to reproduce. It is an abundant seeder, grows very rapidly, and inhabits a region with every climatic advantage. In the typical fir districts of Oregon and Washington deforested land which escapes recurring fire is usually restocked naturally and with astonishing rapidity.

The exceptions to this rule are where the destruction of seed trees has been wide and absolute, where already established competing species are not removed with the original forest, and where the surviving fir is too old to seed. The two latter conditions are most prevalent near the coast, where the wet climate not only tends to protect slashings from fire and thus preserve the undergrowth of shade bearing species which escapes logging, but has also prevented the accidental destruction in the past of the original fir stand by fire.

In considering these natural results as they bear upon proposed methods, we find actual destruction of seed supply the easiest to avoid. If the original stand contains suitable seed trees we can protect a sufficient number of them. If not, or if it is less expensive, we can secure seed elsewhere. More frequent difficulty will lie in determining whether the reproduction of fir should be the sole effort, or whether it should not be sacrificed, if necessary, in order to utilize an existing start toward a second crop of other species. This is of peculiar and early importance, for it usually also decides the question of protecting the slashing from fire.

If the present stand is nearly pure fir, or if other species are represented almost wholly by merchantable trees, there will be no young growth worth saving. A new crop must be started from seed, and since fir is the quickest and easiest to grow, as well as probably the most raluable, it should be given every encouragement. 


\section{Slash Burning and Its Exceptions.}

In most cases this requires burning the ground after logging, not only to reduce the future fire risk but also to provide a suitable seedbed. Fir much prefers mineral soil to start in, as is easily seen from the far greater frequency of seedlings on road grades than on adjacent undisturbed ground covered with humus and rotten wood. Hemlock has no such fastidiousness, even preferring rotten wood as a seedbed. To protect the slashing from fire, therefore, both preserves the most unfavorable conditions for fir and subjects it to unnecessary competition by its rival. Hemlock seedlings already established, seeds lying on the ground, and surrounding or surviving trees which may seatter more seed, are all eneouraged to shade and stifle the struggling fir seedlings already handicapped by dislike for their situation.

On the other hand, a large proportion of what we now consider typically fir forest has a vigorous ground cover of hemlock and cedar which may become merchantable many years before an entirely new fir crop can be grown. The presumably greater value of the latter may be consumed by the heavier carrying charge before returns are available. Certainly if the promise of profit from other species and the difficulty of establishing fir both reach the extreme, protection of the growth already started is the best forestry if it is practicable. Moreover, there may be considerable young growth of other species under conditions which do not preclude satisfactory additional reseeding by fir.

When the owner is in position to plan far into the future, like the Government or State, he may seek a temporary compromise, although expecting eventually to secure pure fir. In such a case it may often be best to utilize a first new crop of hemlock, but on harvesting this a few decades hence to burn clean and start the next rotation with fir only. 


\section{Conditions Vary Methods.}

Between conditions clearly suggesting one course or another, all gradations will present themselves and no written rule can be given for determining the dividing line. Much depends upon future relative values of species, upon which the owner will have his own opinion. More depends upon the character of existing young growth and consequent adaptability to changed conditions after logging. Even a very thick stand of young hemlock is unlikely to produce much if the overwood has been very dense, for much of it may be so old and stunted by shade that sudden advent of strong light will result merely in distorted worthless branch growth or in killing it outright. Occasional vigorous young trees just under present merchantable size are of doubtful value because they are likely to blow down. The most promising class of undergrowth found in fir forests of the Northwest is where there has been sufficient light to produce a fairly thick stand of young hemlock or cedar from five to fifty feet high.

If the undergrowth from which any second crop may develop is insufficient to be worth much consideration, and reseeding must be depended upon entirely, there may still be a question as to species. If ample natural supply of fir seed can be expected, slash burning is indicated. But if not and the owner is not prepared to undertake the expense of artificial seeding, while at the same time there is a promising natural hemlock supply, burning has no object except the reduction of future fire risk. It may even retard hemlock reproduction, both by destroying part of the seed supply and by encouraging the growth of brakes on the area. The question here is a really financial one. The cost of planting fir under these conditions may be more than reimbursed by the resultant more valuable and rapid growing crop. The owner must do his own conjecturing as to future comparative values of the species.

So far we have discussed slash burning only in its sylvi- 
cultural relation, finding that it encourages Douglas fir reproduction and is consequently advisable in Northwestern Douglas fir types unless there is an exceptionally promising second growth already started. The balance will be further in its favor, in doubtful cases, because of the protective feature. This is discussed more fully in another chapter, but it is well to recall here that immunity from recurring fire is the first essential of profitable reforestation. To secure second growth by treatment which threatens its destruction later is bad management unless the original saring is ample to cover subsequent greater cost of protection. This is seldom the case.

\section{How to Reseed the Area.}

Dismissing the exceptions noted, and returning to our rule that another crop of Douglas fir is usually the best secured by following nature-cutting practically clean, burning the ground and starting a new even-aged stand-we have still to consider means of getting this stand started. We may depend upon natural reseeding from trees preserved for the purpose or from the surrounding forest, or we may resort to planting. What are the comparative adrantages of these two methods and the circumstances governing choice between them?

Hitherto, students of the subject have inclined to favor natural reproduction. The very general second growth on deforested land where no aid has been given indicates that excellent results will follow slight assistance. Red fir fruits frequently and profusely, and the seeds carry well in the wind. Burns have been known to restock fully from seed blown from forested hills a mile or more away. Moreover, while planting always involves initial expense, sometimes much may be done to insure natural seeding with little or no actual outlay.

There is danger, however, that in many instances this economy will be more apparent than real if it is effected by actually leaving much ralue in seed trees. Abroad and in the East there is comparatively little loss in leaving even a fourth or fifth of the original stand to furnish seed. The individual 
trees left may be good seeders, although small. Little capital is tied up in them and they may be utilized later to equal advantage. A mature fir forest of the Pacific coast may have no small fruiting trees at all, and if left such are likely to be knocked down in logging. To leave 20 per cent of the large trees standing would sometimes tie up 20,000 feet to the acre, worth $\$ 40$ or $\$ 50$. Age and windfall may cause loss equal to stumpage increase; moreover, they can never be utilized without the same expense for roads and machinery that is necessary in the original logging. The second crop will not be allowed to reach a size requiring such equipment. In considering possible windfall loss, not the normal wind but the possible maximum storm within the entire life of the second crop must be reckoned with.

It is probably safe to say of mature Pacific coast fir that leaving enough merchantable timber on a cutting area for adequate seeding costs more than to use it and restock. Restocking can be done for $\$ 2$ to $\$ 10$ an acre, which would leave a decided margin for profit on the seed trees. And if we undertake to reduce this balance by leaving very few seed trees, we decrease the certainty of successful reproduction and increase the danger of entire failure through windfall or accidental destruction when we burn the slashing. It cannot be denied, however, that fire after planting would result in complete loss, while seed trees might restock the area again and again after such accidents.

\section{Natural Reproduction.}

On the other hand, natural reproduction does not always require the leaving of merchantable timber on the cutting area. Frequently there are enough crooked or conky trees to serve the purpose. These defects are not directly transmissible through seed to the offspring, although conk is infectious and the young crop should be protected by the removal of the diseased parents after it is well started.

Again, seeding from adjacent timber can often be relied 
upon. This is a question of economy in logging operations, lay of the ground, prevailing wind direetion, fertility of the stand and other local considerations. A valley with healthy fir woods on either side is likely to seed up promptly even if a half mile wide. So is a flat at the leeward foot of a hill timbered on the summit where the wind strikes. A cutting on a ridge is correspondingly unlikely to restoek. 'Theoretically if a tract of timber were large enough, it could be opened up by logging operations which, instead of proceeding steadily from one edge, might skip every other landing or so until the most remote portion was reached after a few years, and then work back again, cleaning up the neglected portions after they had seeded the first openings. The same effect sometimes results from actual accidental practice.

It is apparent that rules eannot be laid down for general application. Generally speaking, a logger interested in fir reforestation should study his ground to see if naturally, or, with inexpensive aid, the cut-over area will not reseed from the sides and from the cull trees he will leave uncut. If not, he may leave a few merchantable seed bearing trees provided the soil is such as to make them deep-rooted and wind-firm. Groups are better than single trees because less likely to be blown down and easier to protect from the slashing fire. More should be left toward the windward edge. But before tieing up any considerable sum in merchantable trees he should consider the cost and safety of supplementing any shortage of natural supply by artificial seeding.

\section{WeSTERN HEMLOCK (Tsuga heterophylla)}

Since hemlock is so frequently associated with Douglas fir, the principles governing its reproduction and its relative promise as a second crop have necessarily been largely covered in the preceding discussion of fir. The following remarks are merely additional.

We have seen that the perpetuation of hemlock is advisable only where fir reproduction is difficult to obtain or will be at 
too great a sacrifice of valuable existing hemlock. The first of these conditions is confined chiefly to pure hemlock stands and to coast regions where the fir is often too old to seed well. The second may exist on the coast or in certain moist interior regions where there is a heavy hemlock undergrowth. In either case natural hemlock reproduction will be counted upon, both because it is practically certain to occur and because if it were not certain and artificial aid were necessary, we would abandon hemlock entirely and derote our efforts to fir. In short, discussion of hemlock as a second crop need not include systematic attempts to seed the ground but may be confined to protection of what we have to begin with.

In a straight hemlock proposition, the protection question may differ considerably from that involved by deciding between fir and hemlock. In the latter case, because of the assistance of fire to fir, the growth already on the ground must have considerable value to warrant foregoing the several adrantages of slash burning. In the former, slash burning has no object except to reduce future risk. The inference is that a much less promising stock of young growth is worth protecting.

While this is true, there is danger of overestimating its value, especially if care is not taken in logging. It has been remarked that suppressed misshapen hemlock is not apt to make a healthy growth, that windfall is a peril, and that if the previous shade has been heavy, sudden opening to sunlight may be fatal. It should also be remembered that even slightly injured young hemlock is worthless, for it is almost certain to be attacked by borers. Anything which deadens a small portion of the bark like axe blazes, fire scorch, or scars from strap leads, is dangerous. Hemlock is more liable than fir to general defects like black streak, borers, fungous disease and mistletoe, therefore investment in reforestation needs the maximum safeguard against them. In many instances better results may be obtained from a new healthy seedling stand following a purifying fire, even at some loss of time, than from well started young growth which is unhealthy and likely 
not only to fail itself but also to infect any seedlings which may come in among it. Consequently if the slashing is not large, and reproduction from the sides may be counted on, the above considerations, coupled with the reduction of future fire risk, may suggest slash burning just as in the case of fir. T'he remarks apply particularly if it is considered necessary to $\log$ as elean as possible.

With a good, healthy start toward a new forest, however, it will usually be best to keep fire out, for the material saved will warrant greater expense in protection during the growing period. Representative tracts, both on the coast and in the Cascades, have been studied which showed that, with care in lumbering, enough good young hemlock too small for logs or skids conld be saved after present-day logging of a heavy mixed fir and hemlock stand to produce in fifty years 11,000 or 12,000 feet of timber over 14 inches in diameter. This would not be wholly additional to the seeond erop of seedlings which might be produced if these trees were not preserved, for the ground and light they use would be denied to the seedlings, but undoubtedly the yield would be greater than could be seeured if they were destroyed.

This means that under similar conditions we may go still further and actually apply the selection system, especially if the original stand is nearly pure liemloek. So far we have diseussed areas left by present-day logging methods. Suppose, however, the owner of a good tract of hemlock, having decided that conditions do not warrant trying to get fir, is willing to modify his methods for the sake of better hemlock returns at some future cutting. He would probably do best to take out only the mature trees, leaving everything which is still growing with fair rapidity. Greater light will stimulate these immensely as well as eneourage further seeding of the grouncl. The few merchantable trees he spares, together with those now unmerchantable, will, in perhaps twenty years, make another excellent crop. By leaving a fairly dense stand he prevents the windfall danger which threatens the survivors of too vigorons eutting, and also prevents them 
from assuming the branchy form of trees which receive too much side light. The fire danger is much reduced by resultant shading of the ground and slightly by the lesser cover of debris. In short, he makes the most economical use of the ground, and the capital represented by the trees he spares is well invested.

To sum up, hemlock lends itself to almost every form of management. Determination as to which is most advisable is governed by its extremely variable manner of occurrence and by the local promise offered by associate species. The foregoing discussion can only serve as suggestive when considering given conditions.

\section{Western Cedar (Thuya plicata)}

Except for small swamp and river bottom areas, where the land is likely to be more valuable for agriculture than for forest culture, pure cedar stands are not common. Therefore it is as a component of mixed stands that cedar is likely to become a problem in conservative management. To some extent it presents a peculiar question by being taken out alone for special purposes, such as poles and bolts, independent of ordinary logging of sawtimber.

Western cedar is a typically shade-bearing tree and also endures much ground moisture. Its occurrence as an under story and in swamps does not indicate that it always requires such conditions, however, but more often means merely that they protected it from competition or from destruction by fire. Charred remains of very large, fine cedar are often found on comparatively dry slopes where fire has resulted in complete occupation by fir at present. Cedar's failure to reappear there after removal is probably because its thin bark and shallow roots allowed its destruction by a fire which was survired by some better protected fir seed trees. Nevertheless, cedar must be classified as a moisture-loving species and occupies dry soils only in coast or mountain localities where there is a compensating heavy rainfall. 
Peproduction and management of western cedar have not been sufficiently studied to warrant very positive conclusions. This neglect is probably due to a wide belief that in spite of its present commercial importance, its place in the future forest will be small. It most commonly occurs with other trees in heavy stands, which make the preservation of any young cedar difficult because of the destructiveness of logging. Being of comparatively slow growth, also persistent in retaining branches when grown in the light, it is not as promising for artificial reproduction as Douglas fir or white pine. To let it become old enough for good shingle material will be too expensive to pay, for roofing is one of the wood products casiest to substitute for. While cedar is adapted for poles, posts and other underground use, less decay-resisting species can be made equally durable by chemical treatment. In other words, as a second crop it is probably below other species in ease of establishment, rapidity and quantity, and will not have sufficient peculiar value to compensate for consequent less economical use of the ground.

There may be exceptions to this rule. Good young cedar in forests which are to be handled under the selection system should be carefully protected. It can always be utilized and may bring revenue before anything else can be cut. For the same reason it has been suggested for planting with fir and white pine, either simultaneously as a small proportion or later in blank spaces where the others fail. Under such conditions the main stand will not be modified and the cedar will afford a valuable adjunct.

\section{SitKa Spruce (Picea sitchensis)}

Although found in the moister mountain regions, this exccedingly valuable tree seldom occurs to a commercially important extent except along the coast, where it is common on swales and fertile benches and in river bottoms often forms pure stands of great density. Yields of 100,000 feet an acre 
are not unusual and the trees are very large. It is also common, although of small size, in swamps.

This spruce reproduces readily in openings, whether made by fire or cutting. Unthrifty specimens may be found under shade, but considerable light is necessary for successful development. Even then, height growth in youth averages slower than that of fir or hemlock. The leader shoot is likely to die, so that hardly more than 25 per cent of the young trees establish a regular form of growth before a height of 20 or 30 feet is reached. After this stage spruce grows uniformly and rapidly, still somewhat slower than fir in height but exceeding it in diameter. The branches are slow to die, however, so that the tree remains bushy for most of its length until it reaches 60 or 80 feet in height, and even afterward a dense stand is required to clear it. In many pure spruce forests the larger trees have been able to withstand the pruning influences and remain limby, while the smaller ones, being pushed in height growth to reach sufficient light for survival, have cleared themselves with remarkable rapidity.

The natural occurrence of Sitka spruce, except in Alaska, is probably limited chiefly to situations where it escapes competition, in youth at least, with the more hardy and rapidgrowing species. It has the greatest advantage over these on river bottoms and flats where there is a dense growth of deciduous brush and where the soil is very wet in spring. In considering it as a possible second crop, the same competition must be remembered. Whether seeding is natural or artificial, the extent to which it will hold its own with any considerable quantity of other species is doubtful. If such are present and the situation is adapted to them, any expensive effort to get spruce merely by modifying methods of logging or handling the slash is certainly likely to be disappointing. Under the conditions mentioned as peculiarly favorable for spruce, gradual natural restocking may be expected if some seed supply is preserved, but since the growth is rather slow and a thin stand will remain limby, it may pay to hasten 
returns by supplementary artificial planting. Some authorities question the financial practicability of this on the ground that since spruce is of slower growth it will pay better to use the ground for fir, but the latter is unlikely to be true of bottom land.

After summing all its advantages, the peculiar merits of spruce for certain purposes should be weighed, for sufficiently higher stumpage value will compensate for delay in harvesting the erop. Moreover, Sitka spruce has not been as thoroughly studied by foresters as the more prominent Western trees, and while the foregoing notes represent general present opinion, further figures on rate of height growth may be more encouraging. 'There is no donbt that diameter increase is rapid from the start. Most of the disadvantages mentioned also decrease toward the southern limit of the spruce range, the growth on the Oregon Coast being rapid.

\section{Western Yellow Pine (Pinus ponderosa)}

In this species we have the important western conifer which most often permits the selection system of management. With certain exceptions in which the entire stand is mature, the object of conservative logging should be to remove trees past the age of rapid growth and foster those that remain for a later eut. When comprising the entire stand, or at least clearly dominating it, with all ages fairly evenly represented, successful in reproduction, and not so dense as to present mechanical difficulties, it is ideally adapted to this form of management. 'The important underlying principle is that, since for a period of its life the normal individual tre increases in wood production and then declines, it is bad economy to eut it while it is still growing rapidly or to allow it, after slowing down, to oceupy ground which might be used by a tree still in the rigor of production. For example, if at 100 years old it contains 500 board feet, it has averaged an addition of 5 feet a year throughont its life. If at 125 years old it contains but 560 feet, the average increment will be but 
$41 / 2$ feet a year. It will not give equal return for the soil, moisture and light it monopolizes during these 25 years. At the same time, probably there are young trees nearby which hitherto have averaged below the maximum, but if released from its competition will forge ahead for a period at the end of which they will give a greater annual return than if cut at present. It would be as bad economy to cut these today as to spare the over-mature tree. In short, the production of the forest is not only sustained, but actually increased, by removing the oldest trees at just the proper time; and is decreased by taking out young trees either not yet at the natural age of greatest mean annual increment or capable of artificial stimulation by thinning.

By studying the relation of age to production in the particular locality, the proportion of different age classes, and also finding the approximate average diameter which corresponds to the age at which he desires to cut, the professional forester can make a very accurate selection of the trees which can be removed to best advantage at present and also fix the time and yield of the next cutting. Fortunately, however, commercial and silvicultural considerations accidentally coincide so nearly under arerage yellow pine conditions as to make certain rough rules which can be laid down entirely consistent with logging methods now in practice. Diameter is far from exact indication of age, for the location of the forest and the situation of the individual tree, especially as it affects the relation between height and diameter growth, are potent factors, but as a rule merchantability for saw-material is not far from maturity.

In a great majority of cases the approximate minimum diameter for cutting which would be fixed by a forester would be somewhere between 16 and 30 inches, but say it were 18 inches, for example, it would not arbitrarily apply throughout the stand. Most trees with yellow, smooth bark and small heavy-limbed tops, perhaps partially dead, are mature regardless of their size. If small, they have been crowded or stunted and may as well be cut. Trees with large, healthy crowns 
composed of many comparatively small branches, and with rough dark bark showing no flat scaling, are sure to be growing rapidly, even if quite large. They are also less desired by the lumberman, who often calls them black pine or black jack, so may often be spared, without much sacrifice, for seed trees or in order to continue their rapid wood production.

The seed tree problem in such a pine forest and under suen a system as has been described is comparatively simple, for there are likely to be enough young trees of fruiting age left to fill up the blanks between existing seedlings. The density of the latter determines to a large extent the number and location of seed trees necessary, but there should always be two to four to the acre, even if this requires leaving some that would otherwise be logged.

Under this system recurring cuts may be made at periods of perhaps 30 or 40 years, taking out each time the trees which have passed the minimum diameter since the last previous cut. It is obvious, however, that if the process is to continue indefinitely, protection must be absolute. Destruction of young growth will stop the rotation at the time the surviving older material is harvested. At each cut the brush should be disposed of with this end in view. If the stand is very thin it may not add much to the danger of fire and, especially if reproduction is difficult and requires shelter, may best be left spread on the ground at some distance from remaining trees. Otherwise, and this is the rule, it should be piled and usually burned. In this process and in logging every effort should be made to protect existing young growth from injury. Ground fires should be prevented now and always hereafter.

So far, however, we have been considering how to make the most of a stand of many ages, due to constant reproduction permitted by the light supply in a fairly open forest. On the other hand, yellow pine sometimes produces a mature stand so heavy that there is little young growth beneath it, or even a thin old stand with either little reproduction or an invasion of lodge-pole pine. Such conditions are usually due to fire at some period. In the first of these cases, usually the dense 
stand has resulted from a fire which destroyed its predecessor not so completely as to remove the seed supply, but sufficiently to afford light for a more uniformly dense crop of seedlings than would occur in the normal forest. These have been thinned out as the stand grew old, but never to a degree which allowed much reproduction beneath them. The natural cycle will be begun again in time, for toward the end of the life of this unusually heavy stand, seedlings will begin to appear gradually as individual old trees die and admit more and more light. The other exceptions described are due to more recent ground fires which have destroyed only the less hardy young growth and perhaps also encouraged the lodge pole which, within its range, is always quick to take burned ground.

The same result is almost sure to follow the "Indian" method of forest protection sometimes advocated, which consists of purposely running ground fires frequently in order to prevent accumulation of sufficient debris to make an accidental fire fatal to timber of commercial size. While such immunity may be secured, and perhaps without sacrifice in stands so heavy as to have no reproduction or when the latter has already been destroyed, it is obviously at the expense of young growth if any exists. The counter argument that a small proportion escaping will be sufficient for the second crop is fallacious, because good timber will not be produced from these scattering seedlings subjected to strong light by later logging. Other means are necessary if the forest is to be reproduced.

This brings us to the possible management of yellow pine as an even-aged forest. Thoughtful foresters are beginning to suspect that while the "Indian" system of fire protection will usually be fatal if ordinary logging practice is followed, it may serve as an adjunct to a system which, if carefully applied, will be better than selection cutting for some of our pine areas. This plan is suggested where there is little young growth worth protecting and consists of depending upon seed trees almost entirely for reproduction, protecting carefully 
until the resultant even-aged second growth is large enough to stand slight fire, and then burning periodically at such a season and with such safeguards as will prevent the fire from being injuriously severe.

Not only are there many existing forests where absence of small trees will permit clean eutting without sacrifice, but the same condition is likely to oceur eventually in stands following seleetive logging if the second ent is long delayed. Although a good representation of all ages under the diameter limit remains, the density of this may become too great to allow further reproduction, and in time the dominant trees will shade out all smaller growth. To allow this purposely, choosing heavy cuts at intervals long enough to mature the crop from seed rather than frequent light euts of a constantly replenishing stand, thus redueing the necessity of fire prevention, is the aim of those who favor clean eutting as the most practieable system. They assume that additional investment in seed trees, or planting to insure prompt starting of a new crop after cutting, will be unnecessary or at least offict by the smaller fire charge and greater economy of logging.

Theoretieally, such practice with a speeies adapted to the selective method is uneconomical, for the ground is not fully utilized. Aceidental open places in the stand are not ocenpied by young trees which would otherwise fill them. Time is lost by not starting the seeond crop until after logging, for were there no fire previously there would be considerable seedling growth which, although perhaps dormant because of shade, would begin to amount to something much quicker than that supplied by seed trees afterward. Nor is the system feasible where there is mueh fir or other species less fireresisting than pine. It is dangerous in practice except where there is very little comloustible matter on the ground and fire is generally easy of control, and exeeedingly dangerous to advocat: besuse it serres as a pretext and example for indiscriminate carelessness with fire under all eonditions. Finally, the alleged immunity of pine from injury by ground fires is exaggerated. As a matter of fact, while the whole stand is 
seldom perceptibly hurt, the immediate or gradual death of a good tree here and there thins the stand very considerably in a few years and it is such a thinning process in the past which makes many pine tracts bear but 5,000 feet to the acre where otherwise they would yield two or three times as much. Scorching also retards the growth of trees not actually injured otherwise.

The technical objections given above may sometimes be offset by practical advantages and the system is likely to receive expert approval for certain conditions provided it is not used as a cloak without taking sincere steps to replace the destroyed second growth by adequate seed trees or artificial seeding. The latter danger may easily warrant public alarm manifested by restrictive laws. Universal ground burning of green timber will distinctly reduce the prospect of unassisted natural reforestation on the great area of potential timber land in which, as a resource, regardless of ownership, the public is vitally interested. Under present conditions at least, a large proportion of this is likely to be logged without any view to a future crop. It is questionable whether any state should, or will, legally approve ground burning except under stipulation of proper management thereafter.

Unfortunately, it is necessary, in concluding this discussion of yellow pine, to admit that while an attempt has been made to outline the methods which will insure a second crop, the promise of satisfactory financial return is more doubtful than that offered by some other species. Compared with the typical coast trees, such as Douglas fir, spruce and hemlock, the growth is slow and the yield small. The chief circumstances in its favor are low land values, lesser fire risk, cheapness and certainty of reproduction and excellent market prospects. Less investment compensates somewhat for longer rotation and smaller yield. Low taxation, however, is an absolute essential. 


\section{Western White Pine (P. monticola)}

Although as a distinet forest type this valuable tree is limited chiefly to Idaho, it occurrs oceasionally in mixture or small tracts over a wide range, and no reason appears why its commercial importance should not be extended by planting on cut-over lands. Its high value, rapid growth and heary yield make it a particularly promising species for growing under forestry principles. Its chief requirements for success are fairly good moist land, access by the seed to mineral soil and ample light for the young seedlings.

Except that it is more fastidious as to soil, white pine usually demands about the same treatment as that prescribed for Douglas fir, including clean cutting, slash burning and establishing a new even-aged stand by seed trees or artificial restocking. Under favorable conditions the stand is nearly even-aged, with little undergrowth except of undesirable speeies. What small pine may exist is seldom thrifty enough to be worth saving, so the best thing is to elean off the ground for the double purpose of removing weed trees and favoring valuable reproduction. Like that of fir, the natural rotation of white pine forests seems to have been aceomplished often by the aid of fire, and where not given this aid it suffers from lack of suitable seed-bed and from the competition of other species already established.

Individual seed trees left in logging are not successful because of shallow root system and almost certain windfall. Replacement must be by seeding or planting, or by leaving small tracts of pine surrounded by cleared fire lines to protect them when the slashing is burned. The size and distance apart of these must be determined by their situation and exposure to wind, considering both the danger of windfall and the carrying of seed. Especially in younger growths, the quantity of merchantable material tied up in this way is not so great as is sometimes necessary in the ease of red fir, where single seed trees may contain several thousand board feet. On the other hand, stumpage value may be high. For this 
reason artificial replacement may often be more profitable, especially where there is reasonable safety against recurring fire.

A thing to be borne in mind is that white pine seems to reach a healthier and better development when mixed with a small proportion of other species, such as cedar, tamarack, spruce, lodgepole pine and Douglas fir, so there is no object in trying to produce an absolutely pure stand. Some authorities think that 60 per cent of pine, with the rest helping to prune it, is an ideal mixture.

\section{Lodgepole Pine (P. Murrayana)}

Present interest in private reproduction of this species hardly warrants treating it at length in this publication, although unquestionably it will eventually occupy a higher place in the market than at present and its readiness to seize burned land in many regions will make it a factor whether desired or not. Where yellow pine will grow, the problem is most likely to be to discourage lodgepole competition.

In strictly lodgepole territory, however, it may be the only promise of a new forest. Generally speaking, an even-aged growth should be induced by clean cutting if the entire crop can be utilized. Slash burning in such cases is desirable. The chief difficulty is in providing seed supply, for either individual seed trees or small groups are almost certain to be blown down. Experiments so far indicate that heavy strips must be spared, chosen to afford the least present loss and safeguarded by fire lines.

In some lodgepole stands, especially where only certain sizes are marketable, the cutting practically amounts to thinning. Here obviously the effort should be to prevent overthinning and to remove debris with the least damage to the remaining stand. Piling and burning is essential. 


\section{Sugar Pine (P. Lambertiana)}

This extremely valuable pine, commercially limited to the Oregon and California mountains, is fastidious in its ehoice of conditions. Not a frequent or prolific seed bearer, it still insists on a moist loose seed-bed and prefers the natural forest floor to burned-over land. It cannot stand drought when young and except on cool northern slopes seedlings may be killed or stunted by exposure to full sunlight. On the contrary it demands more and more light as it grows older and will be suppressed or killed if unable to secure it. Under natural conditions it perpetuates itself best by filling open places in the forest.

For the above reasons, sugar pine is naturally a component of mixed forests and it is doubtful whether it will be suecessfully grown as a pure stand. Unfortunately, also, logging methods which are both the simplest and most favorable to the reproduction of its associates may be discouraging to sugar pine reproduction. Nevertheless, its value warrants strong efforts to favor it and is an argument, where considerable young sugar pine exists, against either clean cutting or the use of fire.

The Forest Service, for which authority much of the above discussion of this speeies was taken, offers the following general outline for management in California :

"Since the forests in which sugar and yellow pine occur vary greatly in composition, the method of treatment must also vary. For this the forest types already distinguished may form a basis.

"On the lower portion of the sugar pine-yellow pine type, where sugar pine forms but a small proportion of the stand, only the yellow pine should be considered for the future forest. All merchantahle. sugar pine may therefore be removed. It will be necessary to leave only a few seed trees of yellow pine to restock the ground, although usually it will be a wiser policy to leave a fair stand, since this ean be removed as a second cutting when reproduction is establisher. This 
procedure would also hold for areas on which yellow pine occurs in nearly pure stands. In these localities dense stands of second-growth yellow pine occur. It will often be profitable, where there is a market at hand, to thin these stands when they are about 30 years old, removing the suppressed trees for mine props. Trees 6, 8 and 10 inches and up are used for this purpose, and sell for from 5 to 6 cents a running foot.

"On the upper portion of the sugar pine-yellow pine type, where both species have about an equal representation in the stand, seed trees of each should be left, wherever practicable, in the proportion of two sugar pines to one yellow pine.

In the fir belt, where sugar pine and fir are the principal species, the fir should be cut clean wherever possible and sugar pine should be relied upon for the future forest.

"On all lands, the Douglas spruce, white fir and incense cedar should be̊ cut whenever possible, and chutes, skidways and bridges should be constructed from the two last named species."

The following specific instructions are issued for marking timber on National Forest sales in the sugar pine-yellow pine type:

"Owing to the large size of the trees, marking in this type of forest should be done with special care, since a slight mistake involves a comparatively large amount of timber.

"On nearly all of the lands included in this type the ground is now but partly and insufficiently stocked witl young timber, the areas of forest are constantly becoming more accessible to markets, and there is every indication of a strong future demand at greatly increased prices. On nearly every tract, a second cut can be made within thirty years. All marking under present sales should be done strictly with reference to two points:

"1. Stocking the eut-over land as fully as possible with sugar and yellow pine.

"2. Securing a second cut within thirty years.

"All cutting should be done under the 'selection system," 
which requires a careful choice of the individual trees to be removed. Fixed diameter limits and the leaving of any specified number of seed trees per acre can be very largely disregarded.

"The condition of every sugar and yellow pine on the sale area should be studied closely to determine whether that tree will be merchantable thirty years hence, by which time a second cut is probable. As a rule the trees which will remain merchantable for another thirty years should be left. Suppressed and crowded trees which cannot derelop should be removed. Under this system of marking, ordinarily about one-half of the present stand of merchantable pine would be left uncut. Will it pay?

"On areas where practically all of the pine is over-matured and would be cut under the rule given above, a sufficient stand must be left to reseed thoroughly the cut-over land. This requires not less than four full seed-bearing trees, at least 25 inches in diameter, per acre. The strongest and thriftiest trees available should be selected for this purpose, but not less than the number specified must be left even if every tree will be a total loss before a second cut is possible.

"Extensive areas of pine timber which are not yet fully mature should be excluded from the sale. On patches or small areas of immature pine, which it is not practicable to exclude from the sale, cutting should be very light, limited to one-third or less of the largest trees, or omitted altogether.

"No attempt to discriminate sharply between sugar and yellow pine should be made, as both trees are almost equally desirable. Where a choice is necessary, sugar pine should be favored on moist situations, as in canyons, moist pockets, or benches and on northerly exposures. Yellow pine should be favored on dry situations, including exposed ridges and southern exposures.

"Fir and incense cedar should be marked, as a rule, to as low a diameter as these trees are merchantable in order to reduce the proportion of these species in coming reproduction. It is essential, however, that no large openings be made in 
the present stand since the exposed ground is in danger of reverting to chaparral or of becoming so dry from evaporation that no reproduction will follow cutting. Where the stand of pine is insufficient to reseed thoroughly and protect the cut-over area, enough sound, thrifty fir and cedar should be left to form a fairly even cover with openings less than a quarter of an acre in size."

The under current of all opinion upon sugar pine up to date is that reproduction will not be very successful unless enough growth to shelter the seedlings remains after logging. Where the fire risk permits, the same end may be furthered by leaving the tops scattered on the ground.

Little experimenting has been done in planting sugar pine, but there are many indications that except where conditions strongly favor natural reproduction it will be resorted to eventually if any particular attempt is made to get this species. Leaving large seed trees is not only expensive, but rather uncertain, because heavy seed years are several years apart and squirrels consume a large portion of an ordinary crop. Transplants which have received nursery shelter until past the greatest danger of drying out should prove most successful on heavily-cut south slopes.

\section{REDWood (Sequoia sempervirens)}

Although probably the most rapid-growing of all American commercial trees and also of high market standing, redwood has been little studied by foresters. The layman is still more confused by its many peculiarities. Growing to a size of 20 ftet in diameter and 350 feet high, reaching an age of well over 1,000 years and seldom reproducing by means of seed, it is not surprising that it was long regarded as ill-adapted to second crop management. Although observing that suckers sprout from the stumps with great rapidity, the lumberman generally regarded these mushroom growths as abnormal and temporary, and believed his virgin timber to be the finally- 
vanishing remuant of a prehistoric species unsuited to pres('nt-day eomlitions.

It was next discorerest that the suckering labit is no new one. incleed that the niajority of the present stand, however old, began as sprouts from roots or stumps of its predecessors. This is evident from the circular arrangement of several trees around the spot where their parent stood. These old sprouts were of very slow growth, for they were shaded by a forest of extreme density. Is seedlings they could have neither gorminated nor grown, but as suckers they were kept alive hy the parent until light supply became available through their increasing height or through thimning of the forest. Tnder such conditions renturies were required to produce large trees.

The owner of today, ly entting down the old stand, gives the sucker's (onditions hitherto unknown to the redwood. The vigor and susceptibility to the aid of light, which originally was necessary in the sprout growth to perpetuate the species at all. now respond to entire freedom and light in an astonishing manner. Even after severe slashing fires char the stumps, the latter throw out clusters of sprouts which grow several feet a year. Iogging works 30 or 40 years old have come up to trees nearly 100 feet high. Naturally such timher has a heavy percentage of sapwood and is soft and brittle, lut it is alrearly suitable for piling, box lumber and like purposes and improves constantly.

Since reproduction by seed does not enter into the problem, financial possibilities depend almost wholly on the nature of the original stand. There are many tripes of redwood forest, pure and mixed, flat and slope. If the old trees are few to the acre, the sprout clusters will he so far apart that excess of side light will produce clumps of swell-butted, short limby trees, of little use for lumber; that is, unless there is also a seedling growth of fir or other species to fill the hlanks and bring up the density. Where such a nurse growth is to be counted on, or where the redwoot trees are 
small and close together, ideal conditions for a certain, rapid and well formed second crop exist.

The thinner the original redwood stand, the greater the effort necessary at the time of logging to obtain the required density. The leaving of seed trees of other species, with as many as possible small trees of both redwood and other species and the maximum protection of all from fire, should then be the means employed. On some tracts the proportion of redwood will not warrant this effort; on some it is not even required. The question of whether it pays to hold redwood land is therefore almost wholly local, but when conditions are favorable it can be answered affirmatively, because of the extremely rapid growth, with less doubt than of almost any other species.

There is some tendency to over-production of sprouts by redwood stumps. Removal of the excess with an ax, saving those closest to the ground and not over-thinning to the extent of reducing the density conducive to height growth and shedding of low branches, improves the chances of those remaining.

\section{SEEDING AND PLANTING}

\section{- Seed Supply}

It has been shown in a previous chapter that the owner of deforested land who desires to secure a second crop may find it necessary or cheaper to adopt artificial measures wholly or in part instead of depending upon natural reproduction. These measures may be of two kinds-direct seeding, in which the seed is sown where the trees are to stand permanently, and the planting of trees grown in nurseries.

Whether artificial reforestation is accomplished by means of sowing seed or planting trees, the first requisite is a supply of tree seed of the desired species and of good quality. Unfortunately for the timber owner who wishes to enter upon extensive seeding operations, the business of collecting and preparing forest tree seed for market has received but 
little attention from old-established seed firms, and it is not always possible to purchase the species and quantity desired. Moreover, the prices charged are often excessive.

In the Pacific Northwest, however, the demand for seed of Douglas fir and Sitka spruce has led to the establishment of a considerable trade in these species, and at reasonable prices, so that where these species are to be used, or only small quantities of other species, the timber owner will probably find it to his advantage to purchase the seed rather than to attempt collecting it himself. Douglas fir seed is quoted at $\$ 1.40$ to $\$ 2.00$ per pound and Sitka spruce seed at $\$ 2.25$ to $\$ 3.00$.

In purchasing seed it is common practice to specify that it shall be of the new crop, because tree seed kept in ordinary storage loses its vitality materially. When properly stored in air-tight receptacles, however, as is now done by some seed dealers, it will retain its germinative power for several years with only slight depreciation. Moreover, fresh seed, if improperly treated, may be of very poor quality, so that the age of the seed is of little value in the determination of its worth and the only sure method of ascertaining this is by means of germination or cutting tests. The latter method is the quickest and most simple and consists of cutting open a number of the seeds and ascertaining the per cent whose kernel is sound, plump and moist. Seed of good average quality should contain not more than 25-30 per cent of infertile seed.

When seed cannot be purchased, it is necessary to collect. Since no species of coniferous trees bear abundant crops of seed each year and often several seasons will elapse between good crops, it is necessary to gather sufficient seed when the supply is abundant to provide for succeeding years when the crop is apt to be a failure.

The seed ripens in the fall, usually during August or September, and the cones should be collected at that time. Pines require two years in which to mature the seed; that is, the cones are not fully formed and the seed ripe until the second 
fall after the fertilization of the flowers in the spring. Most of the other important conifers ripen their seed in the fall of the same season. Shortly after the seed is ripe, the cones open and allow it to disseminate, consequently they must be gathered before this occurs.

The cones are gathered either by climbing the trees and cutting them off from the branches, by picking from the tops of felled trees, or by robbing squirrels' hoards. Where squirrels are abundant in the forest, the last method is the cheapest. Climbing trees is practiced only where the trees are small. When this method is employed, the workmen should be equipped with linemen's belts and climbers. Picking from felled trees is readily carried on except where dense underbrush interferes, as is the case in the ordinary Douglas fir forest.

Trees growing in the open, with large crowns extending down the greater part of the bole, bear cones more abundantly than trees in dense forests, and for this reason collecting from scattered open growths can be done more cheaply than on logging areas. Often large quantities of cones can be purchased from settlers who will collect and deliver them at central points at a stipulated price. When this method is employed, however, frequent examination of the cones should be made to ascertain that they contain the full number of seed, for often opened cones from which a part or all of the seed has been disseminated will be offered for sale. Insect larvæ also often destroy a large proportion of the seed, particularly when the crop is light and care should be taken that the cones purchased are not infested. The prices paid for cones vary from 25 cents to 50 cents per sack for the larger cones, like yellow and white pine, and 50 cents to $\$ 1.00$ for Douglas fir and spruce, depending upon the abundance of the crop.

After the cones are gathered the seed must be extracted and cleaned. Where climatic conditions in the fall of the year will permit air-drying, the cones may be spread out on sheets or blankets where they will be exposed to the sun and wind. Under this treatment they will open in from 3 to 6 days, 
depending upon the weather and the species. Where bad weather will interfere with air-drying, the cones must be dried under cover by artificial heat. This is the method usually employed by professional seed collectors, and where large quantities of cones are to be treated each year special dry houses are constructed and fitted with elaborate drying apparatus. The work can be done most cheaply with such an establishment, but for the ordinary timber owner who expects to collect seed only oceasionally, a makeshift dry-house which will answer the purpose can be fitted up inexpensively in any unused building. The essential features are shelves or trays 4 feet wide arranged around the walls of the room, one above the other and separated about 8 inches apart, and a heating stove placed in the center of the room. The shelves may be made of burlap stretched tight, or, better still, of wire screening of $11 / 2$-inch or $3 / 4$-inch mesh.

After being subjected to a temperature not exceeding $110^{\circ}$ Fahr. for from 24 to 48 hours, the cones will open, allowing the seed to fall out when shaken or pounded. The seed wher separated from the cones is then mixed with a coarse gravel in about the proportion of $t$ to 1 and ehurned to remove the wings. Finally, all foreign matter is removed by sereening and hollow seed blown out by passing it through an ordinary fanning mill.

\section{SEedixg Versus PlaNTING}

The selection of the method of reforestation to employ, whether direct seeding or planting, depends primarily upon the character of the area to be restockerl. 1)irect seeding is usually considerably cheaper when the results are satisfactory, but only on the more faropable sites where moisture and soil eonditions are right is there any assurance of suceess. Even in such cases partial or total destruction of the seed often results from birds and rodents. In exposed situations where the soil is shallow, or where because of climatic conditions soil dries out several inches deep during the grow- 
ing season, the seed may not germinate at all, or the young seedlings may be killed before they have time to send their roots down to the permanent moisture level. In such situations, planting is the only reliable method. If the plant material is of the proper kind and the work well done, satisfactory results are almost certain to follow. Direct seeding is a much more rapid method than planting, and where extensive areas are to be restocked within a short period and seed is abundant, the work can be completed quickly. On the other hand, this method is wasteful of seed beeause a large proportion fails to germinate and the young seedlings often succumb to adverse conditions, so that where seed is scarce or its cost high, planting is the more practical method.

Because planting is the most reliable method it has been the one most largely employed in extensive operations, both here and in most European countries, but thorough tests are now being made of direct seeding and under proper conditions it promises to be fairly satisfactory. The Douglas fir region west of the Caseade Mountains offers the most favorable conditions for direet seeding and except on badly exposed south slopes, or where the growth of brush is exceedingly dense, it is believed this method will prove a satisfactory one for the timber owner to employ.

In the yellow pine regions conditions are not so satisfactory for direct seeding, since this tree oceurs largely in a region of defieient rainfall: However, natural reproduction is abundant throughout many portions of this type, and it is probable that direct seeding will prove fairly successful if the proper methods are employed and if forest conditions have not been too greatly disturbed. That some method of successfully employing direct seeding with yellow pine be found is greatly to be desired, since yellow pine seedlings do not withstand transplanting well, but there is need for careful experimentation before extensive seeding operations in this type by private timber owners would be justifiable.

Western white pine, it is believed, will be easy to reproduce in most of its native situations by direct seeding, though 
the greater scarcity of its seed and the fact that it will be more subject to destruction by birds and rodents because of its larger size may make planting the more practical method.

Trees for planting can either be purchased from commercial nurserymen or grown in nurseries established for that purpose near the planting site. When only a few thousand trees are needed it is cheaper to purchase them, but when extensire operations are contemplated, covering hundreds of acres in which millions of trees will be needed, it is far preferable for the owner to grow the trees in his own nursery. Some initial outlay for the establishment of the nursery will be necessary and a practical nurseryman should be employed, but the saving in the cost of the trees will fully compensate for these.

One, two and three year old trees, the latter once transplanted, are usually employed in planting, the older trees being used for the less favorable sites. In planting they are placed in rows equidistant apart, the spacing varying from 4 to 12 feet, with a general average of about 6 feet. The work may be done either in the fall after growth has ceased or in the spring before growth commences.

The cost of planting, of course, will vary greatly with the age of the trees, the number planted per acre and the accessibility and character of the planting site. With young trees and wide spacing, the cost may be as low as $\$ 6.00$ per acre, while in more unfarorable situations where older plants are used and planting is more laborious it may be as high as $\$ 16.00$. A fair average, however, for those areas which a timber owner would be most likely to plant up is about $\$ 8.00$ to $\$ 10.00$ per acre.

In direct seeding, several different methods may be employed, such as broadcasting over the entire area with or without previous preparation of the soil, sowing in strips, or sowing in seed spots; but observation and experiment have shown that it is necessary for seed such as Douglas fir, yellow pine and western white pine to come in close contact with the mineral soil in order that it may germinate and the seed- 
lings live; consequently only those methods should be used which will accomplish this. Where the area has been burned over previous to sowing and the mineral soil laid bare, broadcast seeding may be employed. Where the ground will permit the use of a harrow good results are obtainable by scarifying the soil in strips about 10 feet apart and sowing the seed in these strips. On unburned areas covered with a dense growth of fern, salal, moss, grass, or other plants, this covering must be removed by the seed spot method. This consists in removing the ground cover with a grub hoe or mattock in spots of varying diameter ( 6 inches to 3 feet) and of various distances apart (6 to 15 feet), and sowing the seed in these spots. The advantages of this method are that a minimum amount of seed is used; the ground can be prepared and the seed covered to whatever extent is desirable, and the soil pressed down. This method is believed to be the one best suited to the greatest variety of sites.

The amount of seed used per acre will, of course, vary with the species and the method used, and the quality of the seed. The following table indicates the approximate quantity of seed of good average quality required per acre for three different methods, the average cost when collected in fairly large quantities, and the number of seed per pound:

\begin{tabular}{|c|c|c|c|c|}
\hline \multirow[b]{2}{*}{$\begin{array}{r}\text { No. seed } \\
\text { per lb. } \\
\ldots \quad 42,000\end{array}$} & \multirow[b]{2}{*}{$\begin{array}{r}\text { Cost per } \\
\text { pound. } \\
\$ 1.50\end{array}$} & \multicolumn{3}{|c|}{ No. pounds required per acre. } \\
\hline & & $\begin{array}{c}\text { Broadcast, } \\
\text { entire area. } \\
2-3\end{array}$ & $\begin{array}{c}\text { Strips. } \\
1 / 2-1\end{array}$ & $\begin{array}{l}\text { Seedspots } \\
6^{\prime} \text { a part. } \\
1 / 2-\quad 3 / 4\end{array}$ \\
\hline Yellow pine & .50 & $10-12$ & $2-21 / 2$ & $1 / 2 / 2-2$ \\
\hline Western white & .75 & $6-8$ & $11 / 2-1 \%$ & $-11 / 2$ \\
\hline
\end{tabular}

The total cost, too, will vary widely, not only because of the different quantities of seed used but also because of the great extent to which the methods are varied to suit the conditions occurring upon the area. Simple broadcasting without any preparation or treatment of the soil will not exceed 20 cents to 25 cents per acre for labor; harrowing and sowing in strips, 85 cents to $\$ 1.10$ per acre, and sowing in seedspots, 
$\$ 2.00$ to $\$ 5.00$ per acre. Upon this basis the total cost per acre will approximate the figures given in the table below:

\begin{tabular}{|c|c|c|}
\hline $\begin{array}{c}\text { Broadeast over } \\
\text { entire area. } \\
\ldots . \$ 3.20-4.75\end{array}$ & $\begin{array}{c}\text { Strips. } \\
\$ 1.60-2.60\end{array}$ & $\begin{array}{l}\text { Seedspots, } \\
6 \text { ' apart. } \\
\$ 2.75-6.00\end{array}$ \\
\hline Yellow plne .............. 5.20-6.25 & $1.8 .7-2.35$ & $2.75-6.00$ \\
\hline Western white pine............ 4.70-6.2. & $2.00-2.40$ & $2.75-6.00$ \\
\hline
\end{tabular}

\section{RATE OF (RONTH ANI) PROBABLE RETURNA}

Of all factors in calculating the finaneial possibilities of second forest erops, the growth to be expected is the easiest to determine with fair aeeuracy. Future stumpage value, tax burden and fire risk are all subject to uneertain influences. but the approximate yield of a given speeies under given natural conditions will be the same in the future that it is now. To predict it requires only study of existing stands without being misled by the influence of eonditions which will not be repeated.

On the other hand, an immense amount of misinformation is circulated because of superficial olservation. Enthusiasts discovering individual trees which have made prodigious growth, or even fairly extensive stands on fertile soil with heavy rainfall, will compute sawlog yields at 40 or 50 years . which are much too optimistic for general application. Others, remembering some stand they have seen in unfavorable loealities, or noting sharle-suppressed trees which will not be paralleled alter the virgin forest is removed, are unduly discouragerl. It is most exsential that yiekl tables be made by trained observers who know how to reach the true average, and that the figures either actually ame from the region to which they are to be applied or are acompanied by a systematic analysis of climatic and other conditions which permits intelligent comparison.

In ealenlating another ricld on cut-oyer land, the system for an eren-aged new growth, such as will follow elean cutting of loonglas fir, for example, is quite different from that 
necessary if the cutting amounts only to selection of the merchantable trees and leaves a fair stand of smaller ones. In the latter case, yield tables based on average acreage production are of little use because so much depends upon the character of the stand which remains on the tract in question. Here the basis must be the rate of growth of the average individual tree. An estinuate by the number in each present diameter class may be made of the trees which will escape logging, showing, let us say for example, about five trees of each diameter from 6 to 12 inches, or thirty-five in all which are over 6 inches. If the growth study indicates that in 20 years there will have been added 6 inches in diameter we can estimate a crop of five trees each of classes extending from 12 to 18 inches. Actually the process will not be so simple, for the different aged trees will not grow with equal rapidity, and several other factors must be reckoned with, but the general principle is to apply rate of growth knowledge to the material on hand, and study of this material is essential.

For predicting even-aged crops resulting from entire restocking, the acquisition of necessary basic information is as difficult, or more so, but its application is far simpler. That the ground will be fully stocked by natural or artificial means must be assumed, but we can also assume that the result will be influenced only by normal locality conditions and not by accidental condition of the present forest. Therefore we use a yield table and not a growth table. This can be made by actual measurement of existing second growth stands of different ages, which proves not only the growth rate but also the number of trees which the natural shade-thinning process results in at different periods of the forest life. The chief danger of inaccuracy in such information lies in basing it on insufficient measurements or in applying it where soil or moisture conditions are greatly different. The latter error can be guarded against, however, by use of growth figures taken in conjunction with it. For example, if a yield table showing 25,000 feet to the acre at 50 years from seed is accompanied by one showing that the average stand it repre- 
sents is 125 higl at 50 years and its average 50-year-tree is 14 inches in diameter, little invêstigation is neeessary to determine whether in any given locality the growth falls far above or below that.

An attempt to reproduce here any considerable number of growth and yield tables would be of doubtful use without more space than is allowed to explain how they are made and used. There are many technicalities, both mathematical and silvicultural, and unfortunately most of the available figures for the Northwest, obtained by the Forest Service, have not been generalized enough for wide popular value. This is particularly true of yield tables whieh necessarily require assuming standards of merchantability. While the best western white pine table assumes that by the time a new erop is eut 7 -ineh white pine will be salable, the best fir table was worked upon a 12-inch diameter basis. Obviously this would show an unfairly greater yield of a pine forest containing trees between 7 and 12 inches and be very misleading in calculating financial results at the same age and stumpage rates; yet without the original data there is no way of redueing both tables to the same basis. As an example, however, to indicate how the financial possibilities of second growth can be arrived at if a systematie study is made, let us take the Douglas fir figures referred to.

\section{Douglas Fir}

These are exceedingly reliable. Measurements were taken by the Forest Service of practieally pure fir on about 400 areas in thirty-five different age stands from 10 to 140 years old, ranging along the western Cascade foothills from the Canadian line to eentral Oregon. Since reforestation investment is likely to be confined mainly to the more promising opportunities, only sueh growth was measured as gave an average representation of the better elass of the two should all the general territory covered be graded in two quality classes of all around ability to produce forests. On the other 
hand, care was taken not to represent the maximum of the better class, data being taken only from permanent forest land and not from rich potential agricultural land which might show unfairly rapid forest growth. The average areas were actually measured and the number, age, form, diameter growth, height growth, board foot contents, etc., of all the trees on them were accurately determined. Trees 12 inches in diameter $4 \frac{1}{2}$ feet from the ground were considered merchantable, and it was assumed they could be used to 8 inches in the top. From this data were prepared tables and dia grams showing the average development of trees and stands under fairly favorable conditions in the region west of the Cascades.

This gave the following yield per acre:

$\begin{array}{cccr}\text { Age of Stand. } & \text { Feet, B. M. } & \text { Age of Stand. } & \text { Feet, B. M. } \\ 40 & \mathbf{1 2 , 4 0 0} & 90 & 70,200 \\ \mathbf{5 0} & 28,000 & 100 & 79,800 \\ 60 & \mathbf{4 1 , 0 0 0} & 110 & 90,300 \\ 70 & \mathbf{5 1 , 7 0 0} & 120 & 101,500 \\ 80 & 61,100 & 130 & 113,000\end{array}$

Let us see how these figures can be used in answering the primary question of the prospective timber-grower: "Will it pay to hold my cut-over land for a second crop?"

Obviously no certain answer can be printed here, not only because no uniform stumpage prices or carrying charges can be predicted but also because individuals may differ as to what profit is necessary to make the investment "pay," so it will be necessary to analyze the situation so each may select the premises which suit his own case and judgment. The investment made by the holder of cut-over land is of two kinds; that represented by the land which otherwise he might sell, putting the proceeds at work in some other business, and the annual carrying charges which otherwise he might also invest differently. The sum obtainable by investing the money available by sale after logging, adding to it yearly the sum required for fire prevention and taxes, and compounding both at a satisfactory interest for the entire period, is prac- 
tically the cost of holling the tract for any given number of years. By calculating this cost upon a basis of one acre, and dividing it by the rield board measure which the same period will produce, the cost per thousand feet of growing a second crop is arrived at.

Against this may be the gross return from the same expected yield at any given stumpage rate. The yield at the end of a 50-year investment will not be that of a 50-year forest, however, for although the carrying cost begins at once, the new forest requires a few years to become established. No exact figure can be set for this. for some seed will spront the first year and some blank spaces may persist several years, but in the tables to follow five years has been allowed for an average. Consequently, instead of calculating on a $28 \mathrm{M}$ yield as the return at the end of 50 years, as indicated in the yield table on the preceding page, the 45 -year yield of $201 / 2$ M is used, and similarly for the other periods of 60,70 and 80 years. These four rotations only will be considered here, for in less than 50 years second growth will probably be too small to be cut at the highest profit, while after 80 years the investment compounds so heavily as to make it improbable that increasing stumpage values will compensate.

Three interest rates have been used in the first table to follow: 4, 5 and 6 per cent, compound. Forest calculations at lower rates are often seen, but it is not believed that less than 5 per cent will be satisfactory to private owners and many will insist on 6 per cent. The fair standard is what the owner can make in other business today, and since he can reinvest his income in the same business, it is reasonable to figure at a compound rate. A few examples are given to show how similar calculations may be made with any set of investment and stumpage factors which appeal to individual judgment. The second table, prepared from the first, shows at a glanec the price that must be received for Douglas fir to make it pay either 5 or 6 per cent compound interest under a range of sixty different conditions of original investment and annual cost. 
It should be borne in mind that, although present land value is made a charge, the value of the land at the time of harvest is not considered. This value is certain to inerease greatly in the long periods involved. Taxation charges will be against it as well as against the timber. Indeed numch land is now held without any regard to possible second growth. It should be assumed therefore that any profit in forest inrestment shown will be increased by the sum obtainable for the land at the end of the same period.

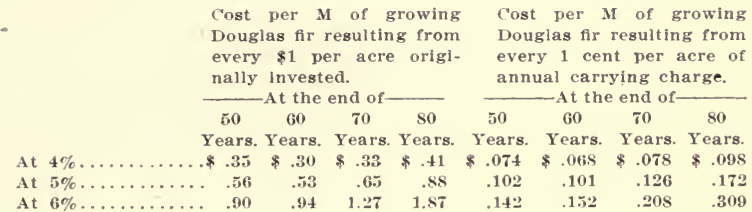

Example 1: With land worth $\$ 2.50$ an acre at present, and an estimated carrying charge of 3 cents a year for protection and 20 cents per taxes, what stumpage price for a 50 year crop will pay 5 per eent compound interest? 6 per cent?
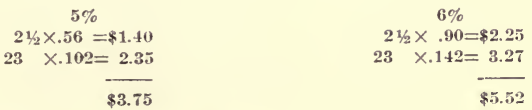

Example 2: With land worth $\$ 5$ an acre at present, and stumpage estimated to reach $\$ 7.00$ in 60 years, what is the maximum annual earrying charge per acre which ean be paid during this period and permit a 5 per cent return? A 6 per cent return?
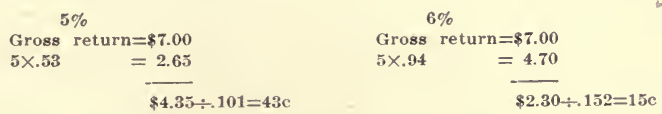

Example 3: Assuming that stumpage will be worth $\$ 6.00$ in 50 years, and that public enlightenment will keep the an- 
nual fire and tax charge from exceeding 20 cents, what price obtainable for cut-over land today, made to earn 5 per cent compound interest in some other business, is as profitable as keeping the land for a second crop? If other business would earn 6 per cent?

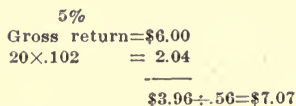

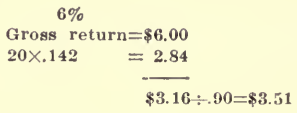

FUTURE STUMPAGE PRICES NECESSARY TO MAKE DOUGLAS FIR SECOND CROP PAY EITHER 5 OR 6\% COMPOUND

INTEREST ON INVESTMENT.

Maximum Original Investment $\$ 7.50$ an Acre. Maximum Annual Carrying Charge $30 \mathrm{c}$ an Acre.

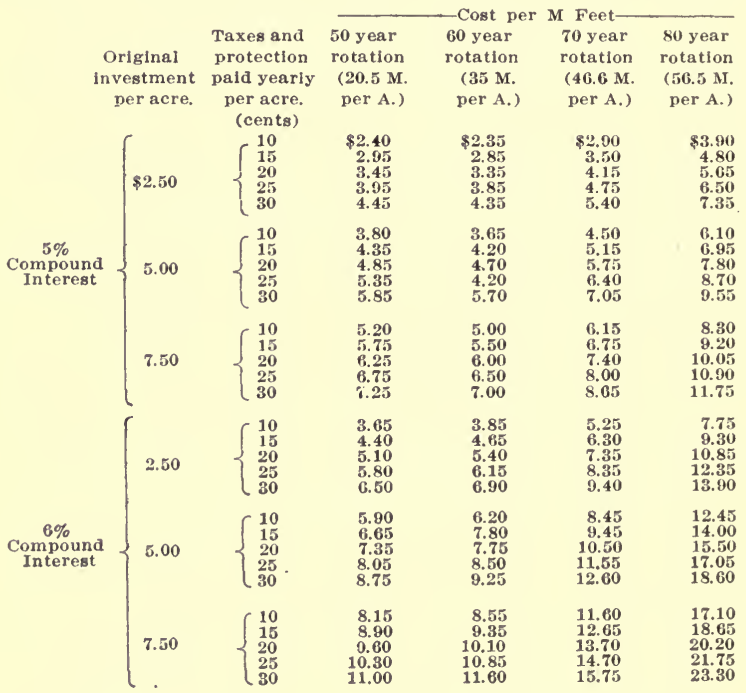

These tables bring out a number of very interesting primary facts : 
1. The rate of interest demanded of the investment is one of the most important factors. This is because such long terms are involved. The charges compound with prodigious rapidity toward the last. In any other business paying 6 per cent, compound, the maximum investment per acre given in the preceding table, that of a land value of $\$ 7.50$ and a 30 cent annual charge for 80 years, would earn $\$ 1,31 \%$. A 75year forest then harvestable should have $56 \frac{1}{2}$ M to the acre, but this would have to bring over $\$ 25$ per M to pay as well. On the other hand, the same deposits earning 4 per cent would only amount to $\$ 338$ in the same period which would be equaled by timber at $\$ 6$ per M.

2. For similar reasons, the length of time before cutting has much to do with profit or loss. The compounding of carrying charges eventually outstrips the production of material to a degree which can be offset only by the most rapid rise of stumpage values.

3. The greater the investment, the more marked the above effect and consequently the tendency to market an inferior product. A 60-year rotation is indicated by a majority of the conditions shown.

4. A comparatively slight increase in annual tax or fire charges may make the difference between profit and loss. Roughly, stumpage must bring $\$ 1$ per $\mathbf{M} \cdot$ more to compensate for each 10 cents an acre for taxes at 5 per cent or for 7 cents at 6 per cent.

5. If the land is salable for $\$ 5$ an acre or more it cannot be made to pay 6 per cent compound interest under the most favorable conditions, unless the stumpage received exceeds $\$ 6$. At $\$ 5$ stumpage and with reasonable taxation it will pay 5 per cent if it escapes fire.

6. Thirty cents an acre is apparently about the maximum annual carrying charge which will permit a 6 per cent profit, even with very high stumpage prices. Consequently, while present taxes on cut-over land are seldom prohibitive, there must be reasonable certainty that excessive increase will not occur. 
The carrying charges shown in the second table cover both fire protection and taxes, as by reading the 15 -cent line to include a 10-cent tax and a 5-cent fire patrol. The investment charge may be used to represent sale value only, or sale value plus any expense incurred at time of logging in order to secure reproduction, such as leaving salable material in seed trees, or planting. If desired, any owner may make a similar calculation on any other valuation better fitting his own situation. The table is not intended for universal use but merely as an illustration of how forest calculations may be made.

\section{White Pine}

Too much space would be required to give a similar table for all western species, even were as good yield figures available. Roughly speaking, however, western white pine, under conditions thoroughly favorable to it, may be expected to make as good a yield as Douglas fir, and the above fir table will not be far off for it. A probably higher stumpage value should offset any lesser production.

\section{HeMLock}

Western hemlock is of somewhat, but nöt much, slower growth when coming in on open land as an even-aged stand. No yield table based on the same merchantable standards as the fir table quoted has been prepared, but the following is fairly safe to include all trees 14 inches in diameter used to 12 inches in the top: At 50 years, $2 \mathrm{M}$ per acre; at 60 years, $22 \mathrm{M}$; at 70 years, $33 \mathrm{M}$; at 80 years, $40 \mathrm{M}$. The absence of a 40 -year figure, and the sudden jump between 50 and 60 years, is because very few hemlock trees reach 14 inches at 50 years, but a large number of 12 and 13 -inch trees pass into. that class during the ten years following. Any yield figures for an even-aged forest show a similar jump at the point where the stand as a whole reaches the determined minimum merchantable size. For the same reason these hemlock figures 
are not very far less promising than those given for fir, for at corresponding ages the latter include 12 and 13-inch trees and all trees are considered merchantable to a top diameter of 8 inches.

\section{SprdCE}

Since no systematic study of Sitka spruce second growth has been made, it can only be predicted from knowledge of its habits that while in favorable situation it will yield as heavily as Douglas fir, in other localities its growth in early life is slower and less regular, making it less likely to produce a good crop before the carrying charges become burdensome. If this proves true, taxation rates and land values will be extremely important factors, offset to some degree by a smaller fire hazard and the probability of high stumpage.

\section{REDWOOD}

For redwood we also lack good figures for any considerable range of conditions and ages, for redwood growth which followed burns does not exist and there are no very old cuttings. Government studies on the northern California coast prove conclusively, however, that this is our most rapid growing native commercial tree. In thirty years, in fair soil, it will produce a tree of 16 inches diameter, 80 feet high, and some existing 45-year stands run 20 to 30 inches on the stump and about 100 feet high. Reckoning 14-inch trees as merchantable, to be used to 10 inches in the tops, a 25 to 30 -year second growth after logging near Crescent City was found to have $21 / 2 \mathrm{M}$ feet to the acre and the future increase should be very rapid. There is little question of the profit of growing redwood, provided the difficulties described elsewhere of getting a dense crop started are overcome. 


\section{PROFITABLE THINNINGS}

In addition to the yield of saw timber to be expected when the second crop reaches manufacturing size, there will be a market in many cases for material obtained by thinning. It is perfectly fair to compound for the remainder of the rotation any net profit so obtained and to set it against the carrying charges. In many cases it will go far to turn an apparently losing investment into a very profitable one. Moreover, the proper thinning of growing stands not only utilizes material which would otherwise die and be lost before the main harvest, but actually improves the quality of the first yield.

In obtaining the figures previously quoted the Forest Service found that the average Douglas fir stand at 40 years contains 410 living trees, most of them between 6 and 15 inches in diameter. At 60 years there are but 265 trees, 145 having died and decayed in the 20-year interval which were suitable for ties or other small timber products. The remaining trees would have been improved by thinning to prevent this loss, for the greatest diameter growth is made when the stand is open, and the ideal is to have just the density which will get the greatest wood production and still result in proper pruning and clearing of the trees.

Commenting along this line Mr. T. T. Munger, who conducted the investigation, says:

"That thinnings are silviculturally practicable and financially profitable in the Pacific Northwest has been demonstrated. In the vicinity of Cottage Grove, Oregon, many fully stocked even-aged Douglas fir stands now about 50 years old, most of them forming a part of ranches. Many of these stands have been eut over in the last 10 years and all the material then large enough for piling or mine timber cut out. This removed about 20 per cent of the stand. At the present time many of these same stands now contain much material valuable for small piles, ties and mine timber, yet the crown canopy is as dense and the trees as close and fine quality as 
though no cutting had ever been done in the stand. In fact, some of the 50-year old stands have already been cut over a second time, and each time with decided profit to the owner and no damage to the forest. From one 10-acre block of second growth now 50 years old, situated 7 miles from the railroad, already 32,000 feet of mining timber and about 10050 foot piles have been taken out, yet the stand is now in good condition, and in a few years more of the smaller trees can be removed without infringing on the yield of the final crop. The material from these thinnings was worth at the railroad about $\$ 80$ per acre."

\section{CONCLUSIONS}

Throughout the preceding pages on the financial promise of timber-growing in the West, the attempt has been not to give conclusions but to state certain known facts regarding tree growth and indicate how these may be used in arriving at conclusions based largely upon the conditions and judgment of the individual owner. In many cases they will do little more than suggest further investigation necessary. The Western Forestry \& Conservation Association and, doubtless, the District Foresters for the Forest Service, will be glad to discuss such work and assist if possible.

There are, howerer, several conservative deductions to be made:

1. The Pacific coast states contain large areas having species and climatic conditions peculiarly favorable for forestgrowing as a business. The rapidity and quantity of yield insure profit under conditions which would be prohibitive elsewhere.

2. In many cases, perhaps in most, a second crop can be started with little initial expense.

3. There is much land of no value for any other purpose.

4. Even if the owner does not care to hold his land Iong 
enough for another crop, or if he is prevented from doing so at some future time by excessive taxation or other prohibition, its disposal value will be greater if it bears young forest growth than if it does not.

5. Stumpage values are certain to advance greatly and their advance will be governed largely by these factors:

a. Speculative influence necessarily accompanying the lessening of the nation's and the world's timber supply.

b. The earrying charges of fire prevention and taxation imposed by the community upon virgin timber, which, since they represent an investment which must be recouped, will either be added in the long run to the price of stumpage exactly in the measure of their severity and so transferred to the consumer, or result in rapid cutting and consequently raise the speculative value of that which escapes cutting. (This the consumer will pay also.)

c. The quantity of new timber grown.

6. It is probable that future demand for timber will reimburse the cost of growing it, be this cost high or low within reasonable limits.

7. This does not mean, however, that the timberland owner will or can generally engage in the business when the cost is excessive. While he could probably make a good profit eventually, such an investment is too heavy and prolonged to be inviting; besides there is the possibility of entire loss by fire. He will naturally compare it with other investments having less disadvantages. For example, since conditions which discourage the growing of new competing forests tend for this very reason to enhance the value of existing forests, he might invest further in the latter instead, with equal ultimate profit and with easier access to his money at any time.

8. Consequently the growing of timber is promising to the private owner only when the investment can be borne easily. Since it has three forms-land value, fire protection, and taxation-all must be moderate or, if one or more is high, the rest must be low. 
9. With the fire hazard great at present, and taxation so uncertain as to require allowing for its being excessive, the initial investment must be insignificant.

10. This confines it to land of low sale value and precludes much expense to insure the second crop.

11. To secure the perpetuation of forests on the scale essential to public welfare, the public must provide the private owner better fire protection and an equitable taxation system. Or else it must purchase sufficient cut-over land and engage in forestry itself, bearing the cost and taking the risk.

12. Nevertheless there are several practical exceptions to the somewhat unfavorable situation theoretically outlined above:

(a) Many owners are warranted in holding cut-over land for some time, if not indefinitely, because of the upward trend of land values generally. Unless clearly most useful for agriculture, such land will be made more valuable by a growth of young timber. However indefinite the profit of encouraging this growth and protecting it from fire may be if the present sale value and taxes are computed against such outlay, the two latter charges are being carried anyway and are the most important ones. Merely that it cannot be proved that they can be more than offset is no reason for not trying to compensate as far as possible at slight further expense. While this may not often permit any great effort to reforest, it will usually warrant protection of the natural new growth that will follow if given a chance.

(b) Many owners would prefer to have their milling business continue indefinitely. If such have or can purchase virgin timber to carry them 50 years or more they may do well to grow a log supply to come into use at that time, even if they would not do so merely as a stumpage investment.

(c) It is highly probable that history will repeat itself in the United States, especially in the Pacific coast states where every other condition is so favorable to making forestry a great benefit to the community, and that fire and tax discour- 
agements will be removed as soon as the public realizes the situation. The owner who anticipates this and gets his crop started first will be the first to profit from it, and since it is the compounding toward the latter end of the rotation which now appears serious, the chances are that he will not have a heavy burden before relief of this kind arrives.

(d) Every owner of virgin timber which he expects to hold uncut for 10 years or more should consider reforestation of adjacent cut-over land in the light of fire protection also. It is the inflammable, sun-dried, brake-covered openings, yearly increasing in extent, which constitute his greatest fire menace. The conversion of these into green young growth, too dense for fern and salal and destructible only by the hottest crown fires, is the best protection he can give mature timber surrounded by them. Some additional expense for a few years to accomplish this will usually be cheaper and safer than the patrol otherwise required for an indefinite period.

(e) Advance in value of the land itself, realizable when the second erop is cut, will in many cases be great enough to make an otherwise unpromising reforestation investment: profitable.

\section{HARDWOOD EXPERIMENTS}

In the foregoing pages consideration has been given to the growing of native coniferous species only. There is a field, however, yet to be entered into by the timber grower in the Pacific Northwest, which gives promise of good returns. This is the growing of eastern hardwoods. As is well known, the supply of native hardwoods in this region is deficient and those occurring are of poor quality. The demand for staple hardwoods is constant, and at present can be filled only through importation from the East. Moreover, the manufacturing industry in the Paeific Northwest is as yet only in its infancy, and as this industry becomes of greater importance in the future, the demand for hardwood lumber is bound to 
increase. This increase in demand, coupled with the rapidly diminishing supply in the East, seems certain to create a condition under which it will be profitable to grow hardwoods commercially.

That eastern species will thrive under forest conditions in this region has not, of course, been demonstrated, but the great variety of species planted successfully as shade trees in towns and cities, and in many instances by settlers in the mountains and farming districts, together with the marked success of various fruits introduced here, would tend to indicate their adaptability to the climate. In many respects the climate along the coast of Oregon and Washington is similar to that found throughout the great hardwood region of the Southern Appalachian mountains.

Of the many species occurring in the East, several appear preëminently suited to experimentation because of their particular value in the trade and rapid growth. Hickory is one of the most valuable of eastern woods, and the supply remaining is probably least of all the important species. It is largely used in the vehicle industry, and because of the fact that the trade can use trees of small size, and even prefers "second growth" hickory to the more mature form, a crop can be grown within a comparatively short time. Shagbark or pignut are probably the best species to plant. Red oak is another species for which there is a large demand, and while it does not equal the white oak in ralue, its more rapid growth makes it a more desirable species to grow. The increasing scarcity of white oak has brought about the substitution of red oak for many purposes for which the more superior variety was formerly used exclusively. Black walnut is a wood highly prized in furniture manufacture, and this, coupled with its rapid growth, places it among the first rank of hardwood trees. Chestnut, white ash, tulip, poplar and black cherry are other species whose value for various purposes suggests the possible advisability of their introduction.

Much that has been said in the chapter concerning the methods of establishing coniferous woods applies equally well 
to hardwoods. Those species, however, whose seeds are in the form of nuts, such as hickories, black walnut, chestnuts, and oaks, are particularly adapted to propagation by direct seeding. Other species, such as ash, tulip, poplar, and black cherry, whose seeds are small, are better grown for one year in nurseries before transplanting into the field. Where plantations are started by planting the nuts directly in the field, the cost will be moderate. The nuts can be obtained in any quantity from eastern seed dealers, and their cost, together with the labor of planting them, should not exceed $\$ 4$ per acre. Where the area planted is level and free from underbrush, preliminary plowing and harrowing, while adding $\$ 1.50$ to $\$ 2$ to the cost per acre, will add much to the success of the plantation. Cultivation during the early years of the life of the trees will also result in increased growth. 


\section{CHAPTER IV}

\section{FORESTRY AND THE FIRE HAZARD}

\section{The Slashing Menace}

The function of fire as an aid to reproduction of the forest in some instances has been discussed in a preceding chapter. The protection question is of even greater importance, for whether we consider mature timber or reforestation, no forest management is worth while if the investment is to burn up. It can be divided broadly under two heads, reduction of risk due to operative methods and general protection. Whichever we consider, the interest of every lumberman is at stake. The fire question affects him in many ways beside the danger of direct loss. The sale value of timber in any region is increased by knowledge that progressive protective methods prevail among those operating there. Nothing more effectively removes public carelessness with fire, or lack of helpful sympathy with the lumber industry in general, than evidence that the lumberman himself is devoting every effort to safeguarding instead of wasting this great public resource.

Of operative methods reducing fire risk, one of the most important is disposal of logging debris. The deliberate accumulation of immensely inflammable material, almost always where extremely likely to be ignited, is a form of actually inviting disaster practiced by no property holders except lumbermen. Nowhere is it carried to such an extreme as in the West, where the refuse left on the ground is of so great volume as to preclude human control if it is once fired at a dry time, and where accidental fire is often more of a 
certainty than a liability. Of late, however, the more progressive lumbermen of the fir region have adopted the practice of firing their slashings annually at a time when the surrounding woods will not burn, and the pine men of Idaho and Montana have quite widely endorsed brush piling. Idaho has a piling law. Oregon already has a slash burning law which is partially observed. The greatest objection to such a law is that neither reforestation nor economical protection indicates the same practice in different types of forest and it is extremely difficult to make the law both flexible and effective. More will be accomplished by voluntary adoption of the method best suited to each condition.

\section{Brush Piling}

In the more open pine stands of the interior, where both logging debris and original combustible ground cover are small, slashings threaten the adjacent timber less than in denser forests, but are of peculiar danger to the valuable young growth usually left on the area itself. As we have seen in a previous chapter on western yellow pine, reproduction in dry localities may require scattering the brush over the ground and keeping fire out, and there may be abnormally dense stands suggesting elean slash burning, but as a rule brush piling is the best course. In view of the importance of this subject the following extracts are taken from a circular issued by the Forest Service:

\section{"Advantages of Brush Burning}

"The greatest advantage of brush burning is the protection it gires against fire. In many cases brush burning is the only practicable safeguard against fire. After the average lumbering operation the ground is covered with slash, scattered about or piled, just as the swampers have left it. 'This, in the dry scason, is a veritable fire trap. Probably 90 per cent of all uncontrolled cuttings are burnt over, which retards the 
second crop at least from fifty to one hundred years and perhaps permanently changes the composition of the forest. Fires may be set by loggers while still at work on the area or several years after by lightning, campers, or locomotives. By piling the brush and burning it in wet weather, or in snow, when there is no danger of the fire spreading, all inflammable material is remored, and the second growth can come up without serious risk of being destroyed. Even where only part of the brush is burned and the rest is piled, as when the piles in open places, along ridges, streams, or laid off lines are burned, very much is gained in case of fire, since these cleared lanes form bases from which a fire may be fought.

"Besides lessening the danger from fire, brush burning has certain minor advantages. When the brush on the ground is remored it is much easier for rangers and others to ride or walk through the forest. This may be very important in case of a fire or in rounding up cattle. It is also much easier to cut and handle ties, cordwood, or other timber which may later be taken from the cut-over areas if the slash is out of the way. By piling and burning the green brush as it is cut from the trees by the swampers, as is now being done in Minnesota and parts of Montana, the ground is cleared and skidding is made easier and cheaper. Again, careful piling and burning of brush improves the appearance of the forest. There is nothing much more unsightly than a recently cutover area where no attempt has been made to dispose of tops and lops. Near towns or resorts and along roads or streams frequented by tourists this point should be carefully considered, but as a general rule the utility of the forest should not be sacrificed for beauty.

\section{"Disadvantages of Burning}

"The disadvantages of burning brush are many and, with the one exception of protection from fire, far' outweigh the 'advantages. If protection can be had in some other way, as with more efficient patrol service or more stringent laws, the 
practice should in many cases be abandoned. In many places, especially in the yellow pine type, the best, and often the only, reproduction comes up under a fallen treetop or other brush. Where there is little of the old stand left, the straggling open top protects the seedlings from the direct heat of the sun. Yet brush not only protects the seedlings from the sun but, what is more important, the leaves and broken twigs form a cover which retards evaporation of moisture from the soil. Over the greater part of the West the soil dries out very rapidly during the dry season, and this serious retards or even prevents the growth of seedlings. Even in the moister regions, such as that of the Engelmann spruce type, it is very necessary to conserve the moisture in the soil after logging to prevent the remaining trees from being killed through lack of soil moisture. A third reason why seedlings so often come up only under the down treetops is that they are protected from stock. Next to drought, sheep are perhaps the most serious menace to reproduction, and though it would be best to keep all stock off the area for several years after logging, in many cases this is not practicable, and on many areas the leaving of the tops on the ground is the only way to protect reproduction from injury.

"In many places after the timber has been" cut off gullies and washes start in the old wheel ruts, log slides, etc., and these and other forms of erosion can best be prevented by leaving the brush on the ground, either laid in the incipient washes or scattered over the soil that is likely to wash. Brush burning destroys the valuable soil cover, and on the spots where the piles are burned the soil is loosened, which renders it even more liable to erosion.

"It is well known that where the forest is burned each year the soil becomes poorer and poorer, because nitrogen, the chief fertilizing ingredient of the soil, is given off in the smoke, and only the mincral clements go back to the soil in the ashes. And, what is more injurious, the humus-i. e., the decomposed vegetable matter in the top soil-is destroyed. In burning brush after logging all the fertilizing and humus- 
forming leaves and twigs are destroyed just when most needed, for another good crop of leaves cannot be expected for many years.

"The added cost, both to the lumberman and to the Government, is another argument against brush burning. The cost of piling brush has varied all the way from 15 cents to $\$ 1$ or more per thousand, with an average of 40 or 50 cents, while the cost of burning may be from 5 cents to 25 cents per thousand, averaging about 15 cents. By abandoning the practice of brush piling this 60 cents a thousand will not be entirely saved, as is claimed by some, for the brush will still have to be lopped and disposed of in some other way, which will cost, it is estimated, at least half as much as piling and burning. But even a saving of 25 or 30 cents a thousand is a strong argument against the practice.

"Thus, from a silvicultural viewpoint, the disadvantages of brush burning far outweigh its advantages. Yet, as a general policy, it seems unwise, until other methods have proved their efficiency, to abandon brush piling and burning to any great extent at present. The fire danger is a known quality, and, though it is being reduced each year, it is still a menace. Therefore changes from the present practice should be made with caution. Brush piling and burning is certainly not advisable in all cases, and extensive experiments should be made to determine what is the best method of brush disposal for the different types and conditions.

\section{"Brush Piling and Burning}

"The cost of piling varies with the cost of labor, the methods of logging, the type, the topography, the kind of trees cut, and the time of the year it is done. A few figures will illustrate this variation. In the yellow pine type in Montana an addition to the swampers' wages of 15 cents a thousand would, it is said, enable them to pile the brush, as they have to handle it anyway. Usually, however, the piling is done by a separate crew. Much of the work is thus duplicated. In 
yellow pine in the Southwest, brush piling costs from 45 to 50 cents, while in Montana it can be done for 25 cents. One operator in lodgepole in Montana says it is cheaper for him to pile than not to, because he can get his skidding done so much cheaper, yet on other operations it has cost from 50 cents to $\$ 1$ a thousand, depending on how thoroughly it is cleaned up. In the sugar pine type of California the cost of piling averages from 25 to 35 cents, while the cost in the Douglas fir type, in Montana and Idaho, averages about 40 cents, and in Engelmann spruce type the cost is only about 25 cents a thousand. It is certain, however, that the cost of piling will everywhere be materially reduced when the operators begin to look on piling as part of the swampers' regular work and not as an entirely separate job.

"Dry brush should never be burned during the dry season, unless absolutely necessary for the suppression of an insect invasion. Green brush in some places may be burned at any time, but as a rule it is unsafe to burn it in dry weather. The best time to burn brush is in the fall, just after the first snowfall. Then the piles are dry, and there is no danger that the fire will get beyond control. Brush may also be burned at the beginning of or during the rainy season, when the ground is damp enough to prevent the fire from spreading, and the brush dry enough to burn readily.

"The cost of brush burning varies like the cost of piling. It varies even more in the same localities, with weather conditions and methods of piling. Brush that can be burned for 10 or 15 cents a thousand at a favorable time, as just after the first snow, will cost five or ten times as much to burn in dry weather, or when the piles are very wet. Brush can be burned more easily the first fall after cutting than it can the second year, when many of the leaves have fallen off. Brush burning has been done for 13 cents a thousand in lodgepole, in the Medicine Bow National Forest, while it has cost 22 cents in similar timber in the Yellowstone, and estimates of 40 cents a thousand have been made for it in the Rockies. It is generally admitted that brush can be most economically 
burned by the same people who pile it. Recently several contracts have been made in which the purchaser of the timber is required to pile and burn the brush under the direction of forest officers, as has been the practice in the Minnesota forest for some time. This will lighten the total cost, and when the weather allows the brush to be burned, as logging proceeds, the cost of burning will be offset by the subsequent reduction in the cost of skidding.

\section{"Piling Without Burning}

"Brush piled properly, even though it is not burned, is a great protection to the forest. Inflammable material is removed from among the living trees, and should a fire occur it would be much easier to fight. This is especially true where reproduction is dense. Where openings are scarce piles should be made in the most open places, and may be larger than those made to be burned."

\section{Slash Burning}

In many regions, especially in western Oregon and Washington, logging debris is too great to make piling practicable. But except for the damper localities close to the Pacific, the danger from these immense accumulations is all the more excessive and, as we have seen elsewhere, their removal is often desirable in order to further reforestation by desirable species. Here the only course is to burn the slashing clean.

This is a dangerous process unless every safeguard is employed. Burning must be at a time in spring or fall when the slashing is dry enough but the surrounding woods are not. Spring burning is theoretically preferable, for it leavęs less inflammable material during the fire season. The first fire is also easier to control then, because repeated experiments may be made, as the slashing dries, until just the right conditions exist. On the other hand, it is dangerous if there are many old stumps and logs in which fire may smoulder to make 
trouble later. The exponents of fall burning also argue that with care they can be ready to fire a very dry slashing safely at the beginning of a rainstorm. Spring burning seems to have the most advocates, but it is doubtful whether any rule for all localities and conditions can be given with confidence. Frequently failure at one season leads to postponement until the next.

In either case the slashing can be given the advantage of the greatest dryness with safety if it is surrounded by a cleared fire line from which to work. Firing should be against the wind and if the wind changes suddenly the opposite edge should be back fired. Previous cutting of all dead trees and snags over 25 feet high is urgently recommended. The camp crew should be held in readiness, well provided with tools, as insurance against accidental escape.

Its probable restriction of insect breeding is a point of slash burning likely to receive much future study. It is well known that most forest-injuring insects prefer dying trees to vigorous ones; also that the existence of an abnormal amount of such material tends to abnormal breeding and consequent serious attack of vigorous timber when the dead material becomes too dry to be inviting. It is by no means impossible that the supposed immunity of Douglas fir from insect injury may be largely due to the almost universal destruction by fire of logging debris which would otherwise afford ideal breeding places.

\section{Fire Lines}

The division of mature forest into compartments separated by fire lines is seldom practicable in this country. Nevertheless slashings, deadenings and similar fire traps can very often be profitably confined by the cleaning of strips which will not only stop or retard the progress of a moderate fire but also facilitate patrol, fire fighting or back firing. On favorable ground, where some choice is offered, much may be done by falling timber inward so as to leave few tops near the uncut 
timber and by the location of skidroads. So far as practicable fire lines should be on the tops of ridges, for, being slower to go downhill than up, fire is more easily discouraged just as it reaches a crest. Bottoms of gulches are next in strategic value, and midslopes least.

\section{SAFEGUARDING EqUIPMENT}

The most fruitful source of fires is spark-emitting locomotives and logging engines. Much data has been collected showing that with oil at a reasonable price its use is economical from a labor-saving point of view as well as from that of safety. It reduces expense for watchmen, patrol, fuel cutting, firebox cleaning and firing. And since it is an absolute prevention, while all other measures merely seek to minimize the risk, it is probable that even where the cost of the oil more than balances these savings it will save in the long run by averting a costly fire.

Where the use of oil cannot be considered, spark arresters are essential. The argument that they prevent draft is not worth attention. It is greatly exaggerated by engineers and firemen prejudiced against innovation or too inattentive to keep their fires up properly and consequently unnecessarily dependent on occasional forced draft. The slight disadvantage involved by the modern improved arrester is not to be compared with the importance of the safety acquired.

- In addition to spark arresters, which may fail or be out of order, logging engines using fuel other than oil should be provided with a constant tank or barrel supply of six to twelve barrels of water and 100 feet of hose with proper pumping attachment. With this a spark fire can be promptly soaked out beyond danger of invisible smouldering in rotten wood or duff. When conditions are dangerous, careful loggers send a man back to each donkey-setting between supper and bedtime to look for possible fires that were not seen when the crew left. Many keep a watchman on the rounds all night.

Railroad rights of way can usually be kept cleaned and 
burned at a cost far less than that of otherwise frequent shutdowns of the entire camp to fight fire or rebuild bridges, to say nothing of loss of timber.

\section{Patrol}

The best way to prevent fire is to prevent it. Putting out fires already started is better than letting them burn, but as the real foundation of a protective system it is about like lowering a lifeboat after the ship has struck. Only by patrol can the incipient spark or camp fire be extinguished before it becomes a forest fire that has to be fought, taking hours or days instead of minutes. One patrolman can stop 100 incipient fires easier than 100 men can stop one big fire. Fires in the forest may never be wholly averted, but patrol will prevent them from becoming "forest fires."

This is why the progressive lumberman no longer waits till forced to lay off his crew to fight, spending in a day or two a patrolman's salary for a season, shutting down his road and mill for lack of logs, and perhaps in spite of all losing several thousand dollars' worth of timber and equipment. It is also why the progressive non-operating owner no longer considers fire loss the act of God, to be reckoned as an investment risk of several per cent. The man who does not patrol his timber nowadays is like a millman who hires no watchman, has no hose or sprinkler equipment, and carries no insurance. $\mathrm{He}$ may escape loss, but by not making a reasonable effort to insure against it he takes a course practically unknown with other forms of property.

Modern fire patrol is systematic. Trained and organized men have definite duties. 'Tools, assistance and supplies are available at known points and without delay. Trails and look out stations, often supplemented by telephone lines, give the greatest efficiency with the least number of men. Above all, the system is based on the fact that results are most truly measured not by the number of fires extinguished but by the absence of fire at all. Settlers, campers and lumber- 
men are visited, cautioned and converted. In short, the patrolman has a certain area in which to improve public sentiment. His success in this is worth more than efficiency in fighting fires due to lack of such success. A system devoted to mere fire fighting to be adequate must grow larger as time goes on. One devoted to preventing fire may be reduced, as time makes it successful.

The cost of efficient patrol varies so directly with the risk that it is almost constant as an insurance investment. Where prevalence of fire, difficulty of handling it, etc., make the cost per acre comparatively high, there is equivalent certainty of greater loss if this sum is not spent. Where the owner is warranted in believing his risk small it costs but a trifle to provide sufficient patrol to insure against it. One to 3 cents an acre is spent in the great majority of successful patrols in ordinary seasons.

\section{Associate Effort}

One of the first lessons learned from the establishment of private patrol in the West was that both efficiency and economy are obtained by co-operation between owners. Obviously if one patrolman can cover the holdings of several, it is foolish for each to hire a man. If a fire threatens several tracts, it is better to share the expense of labor hired to put it out. The same is true of building trails, buying tool supplies, etc. This has led to the forming of associations which at a minimum cost to each member accomplish the many tasks of finding suitable men, having them authorized by the State, supervising and supplying them, paying emergency expense, opening trails, etc. Each member pays his share upon the acreage he represents.

These associations offer other important advantages besides the mere cheapening of work. They are admirably adapted to modifying the cost to fit the season. Beginning in spring with an assessment to cover putting the whole territory under the essentials of supervision and patrol, they can add men 
just as required by the progress of dry-weather and reduce again in the fall. Men can be centralized at danger points better than through individual effort. Exceedingly important is the means they afford of bringing in the non-resident owner, the small owner who is not warranted in employing anyone alone, and the non-progressive owner who would otherwise do nothing but is ashamed to stay out of a general movement.

No tract can be safely considered as an independent unit. No protection confined to it alone is as good insurance as the removal of risk from the district within which it lies. Fire is no respecter of section lines. There is always danger of unusual weather in which it may travel a long distance. It is far better to secure the maximum general safety in the locality than to have guarded tracts alternating with fire traps. Moreover attention to individual tracts does not improve surrounding conditions, and the latter may easily become so bad as to make the cost of individual patrol, as well as the risk, far orerbalance any financial disadvantage at present through co-operation.

Again, the public is far more likely to take kindly to the enforcement of fire laws by an association than to the action of an individual owner against whom some prejudice may exist. Associations greatly simplify co-operation with State and Government in fire work and tend to bring about appropriations for the purpose. They enable uniform and concentrated effort to improre sentiment and legislation. This booklet and the other work done by the Western Forestry \& Conservation Association was made possible by the existence of the local organizations it represents. Their independent local and State effect has been marked.

The bad fire season of 1910 was a supreme test of the associations of the Pacific Northwest. They kept the bad fires in their immense territory down to a number which ean be counted on the fingers and their losses were comparatively insignificant. Yet under the weather conditions which existed the thousands of fires they extinguished would certainly 
otherwise have swept the country and caused a disaster probably unparalleled in American history.

\section{Reforestation as a Fire Preventative}

However progressive the preventive policies adopted, the race between them and the increasing sources of hazard resembles that between armor plate and ordnance in the construction of battleships. While for a given population engaged in pursuits endangering the forests the risk lessens, the total activity increases at a rate which makes the smaller proportionate risk as great in actual measure. This is particularly true of the growth of slashing areas. The virgin forest becomes more and more and checkered by burned and cut-over deadenings, veritable fire-traps open to sun and wind, and, especially west of the Cascades, usually covered by inflammable debris, brush or dead ferns. Each year brings nearer the time when, unless something is done, such will constitute the majority of once forested land and the uncut timber will remain like islands in expanses of extreme danger.

Next to cultivation, which but a small percentage will receive, the safest insurance against recurring fires in these cut.. over areas is a thrifty young second growth. It shades the ground, keeps out annual vegetation that furnishes fuel when dead, and will itself carry none but such furious crown-fires as would be practically unknown were there no openings for them to gain headway in. This is less true of pine, but the rery best protection which can be given a tract of merchantable fir is a strip of 10 to 50 -year second growth surrounding it.

Whether regarded from the owner's standpoint or that of the public, reforestation should be considered as a protective measure of extreme importance. Actual expenditure to obtain it may easily be profitable for this reason alone, for once established it will decrease the cost of patrol thereafter. Were all cut-over land in the Northwest immediately restocked, the fire hazard would be enormously reduced. 


\section{CHAPTER V}

\section{FORESTRY AND THE FARMER}

\section{Cutting Methods}

If there is anyone for whom the practice of forestry is practical and profitable, it is the farmer who owns the timber he uses for fuel or other purposes. His supply of the most suitable material is almost always limited and in any case his method of using it is practically certain to influence his permanent labor expenses. Nevertheless, especially in welltimbered regions, cutting is apt to be with but two considerations - the quickest clearing of land or the easiest immediate fulfillment of some need for tree products-and the passage of a few years brings realization that this early thoughtlessness must be paid for at a high price.

In the first place almost all timber of a commercial species has real and increasing value. If it is young, this value is increasing doubly because of growth. Varying greatly, of eourse, young timber in the Pacific Northwest very often adds from 500 to 1,000 board feet to the aere annually. This annual gain is taking place even if the timber has not reached merehantable size, being like coin deposited in a toy bank which does not open until full. And this is true whether the ultimate use may be for fuel, poles, or salable material like tie or saw timber.

Too mueh land is eleared of young growth, merely beeause such clearing is easy, which is of such low value for tilling or even pasture that its use for these purposes does not pay as well in the long run as would its use for growing timber, 
especially when the investment of elearing is considered. The resulting expanse of charred stumps and logs, producing little but ferns, is a small farm asset at best. The timber it would grow may eventually be a large asset. And the labor of elearing applied to a smaller tract of good land is sure to bring greater returns. An illustration is furnished by two tracts near the end of a recently completed railroad in western Washington. Twenty years ago a settler slashed a large area of presumably worthless sapling fir adjoining his tillable bottom land, set fire to it, piled and burned the remaining poles, "seeded down" a pasture, and enclosed it by an expensive cedar rail fence. The pasture, never useful except in early spring, grew up to ferns, and was finally abandoned. Even the fence was moved. The settler on the next claim left his part of the same sapling growth to grow and this year sold the timber alone for $\$ 1,000$ to a tie mill which came into the neighborhood with the railroad. The moral of this does not apply to cutting alone, but argues equally for preventing fire in second growth.

It is also poor economy, if mature timber exists, to cut rapidly growing young timber for fuel because it is nearer the house or easier to cut. The former has become stationary in production, while the latter, if left, is earning money by growing in quantity and quality. If young timber must be used, and the land is not worth actually clearing for cultivation or pasture, it is usually far better to thin out the poorest trees, thus leaving the remainder stimulated to a more rapid growth, which will soon replaee those removed, than to begin on the edge and take everything.

There is no reason why a certain poor-soiled timbered portion of the arerage claim should not be considered as a permanent wood lot, to be treated with the same interest and prid in making it produce the greatest quantity of forest produts for sale or use that the owner accords his fields. With this point of view established and consequent study given the subject, it will also be easier to decide how large this portion should be. In many cases the result will be abandonment of 
the idea that all forest growth is an enemy, to be destroyed on general principles without calculating what actual profit there is in destruction.

Another point often overlooked in the Pacific Northwest, because of our local tendency to consider the forest only as something to struggle against, is the exactly opposite influence of properly placed tree growth upon sale values if the prospective buyer is from the East or from our own cities or treeless regions. Such are attracted strongly by the grove-like effect of a few trees left around the house. Their desire for this is as strongly ingrained as the average local resident's desire for a completely free outlook to mark his victory over unfriendly nature. The appeal a place makes to a buyer as a pleasant home has frequently as important an influence on his decision as its purely practical merits.

His judgment of the latter, however, is also affected by his earlier environment. If he has lived where farming land is open, evidences of the labor of clearing are discouraging. The untouched forest, being totally beyond his capacity to estimate the labor its removal entails, repels him less than stumps, logs, desolate burnings and like detailed evidences of the work which lies before him. This is another reason why the clearing of clearly fertile land may be better business than the half-clearing of land perhaps best suited for forest growth anyway. Again, not fully realizing the plentifulness of forest products in the new locality, he may actually overestimate the value of an attractive piece of forest land showing evidence of the thoughtful care suggested in a preceding paragraph.

\section{USE OF FIRE}

Above all, it pays the settler in wooded regions to be careful with fire. Properly directed and confined, fire is necessary in clearing land. But there is no profit in allowing uncontrolled fire to spread from the actual elearing to create a snarl of dead, deeaying and falling trees and underbrush. It is usually harder to extend the clearing into such ground than into 
green timber. This added work later is many times that necessary to safeguard the burning in the first place.

In every case that fire ever escaped from clearing operations, the cause was either thoughtlessness or unwillingness to perform certain work. Because it is easier to burn a slashing than to pile and burn; or when a ground burn is desirable, because it is easier to take chances than to clear a fire line around the area and have a force of men present; because burning at a dry, dangerous time will be cleaner and thus save work after the fire; inexperience, coupled with unwillingness to take advice from the experienced-these and like reasons are responsible for the destruction of lives and property worth over and over again the sum that was saved by the attempted economy. And, although this does not save others, the person responsible also usually loses instead of gaining.

Without deprecating in the least the importance of agricultural development or of lightening the useful and not easy task of the settler, it is still terribly true that the agricultural industry and the settler suffer an annual loss through the destruction of improvements, crops and stock by fires from careless clearing that is far greater financially than the saving in clearing cost which was the cause. In other words, agricultural development is retarded instead of advanced by its present careless use of fire.

\section{Planting For Fuel and Timber}

Great as are the timber resources of the Pacific Northwest, there are extensive regions in central and eastern Oregon and Washington where timber is a scarcity, and wood for fuel and farm repair purposes for settlers and ranchers can be obtained only at heavy cost. In such situations it will be a paying investment for the farmer to set out a small plantation simply to produce his own wood for fuel, fence posts and other purpases. It is true that some time must elapse before plantations begin to be productive, but by choosing rapid-growing species and planting closely, the thinnings which will be 
necessary in a few years, eren though the trees be small, will do for the woodpile. T'rees which grow rapidly and at the same time produce good wood are, of course, preferable. If they also sprout from the stump, a little care will maintain the supply indefinitely.

'The choice of species for a woodlot must be governed to a great extent by the location. Many portions of the treeless areas in this region are situated at a high altitude where the elimatic conditions are severe and frosts are common throughout every month of the year. In such locations only the most hardy trees will succeed. Other areas are deficient in moisture, and where this deficiency is so great as to prohibit the growing of agricultural crops by dry farming it is useless to attempt growing trees without irrigation.

Probably the tree most commonly planted in treeless regions has been some species of cottonwood. Lombardy poplar and Balm of Gilead have been great favorites. Cottonwood grows rapidly and is hardy against frost, but requires a never-failing supply of water within fire to twenty feet of the surface. Because of its demands for moisture it will not grow on uplands, but thrives along water courses or where there is plentiful supply of moisture below the surface. Its fuel value is not high, though the quantity of its wood production compensates for its poor quality, nor does it make good fence posts. Where quick growth is the main consideration, however, it is a good tree to plant. The varieties known as Norway and Carolina poplar are the best:

Green ash and hackberry are also hardy against both cold and moisture, but of slow growth. 'Their wood is durable in contact with the soil, making them suitable for fence posts. Where it succeeds black locust combines many of the desirable jualities to the highest degree. It is a rapid grower, makes excellent fence posts and has high fuel value. It is not as hardy against frost as cottonwood and ash, and while it has been planted surcessfully in sheltered locations on high plateaus, its success where frosts occur during the summer months is problematical. A closely related species, honey 
locust, is more frost-hardy but less desirable in other respects, though an excellent tree nevertheless. Other fairly hardy and drought-resistant trees are osage orange and Russian mulberry. 'Their value for fuel and fence posts is high, but they will not succeed in the most severe situations. Box elder is hardy and has been widely planted, but it is of low fuel value and short lived.

In favorable localities at low altitudes, where moisture is abundant either through natural precipitation or from irrigation, the number of species which are adapted to woodlot planting is largely increased. Black walnut, black cherry and hardy catalpa are probably the most valuable of these The latter, however, is sensitive to early and late frosts.

\section{WINDBREAKS}

The planting of windbreaks and shelter belts around dwellings and fields is of prime importance to the settler in an open country. Nothing adds more to the comfort of the dweller than a belt of timber about the home to protect it from the wind. Orchards need windbreaks to save them from injury in a wind-swept country, and gardens are more successful when surrounded by trees. One of the most important functions of the windbreak, however, is the saving of soil moisture within the protected area, for it is a well established fact that evaporation takes place more rapidly when there is a movement of the atmosphere than when it is calm. It is safe to say that a windbreak is effective in preventing evaporation for a distance equal to ten to fifteen times its height.

Some species, because of the form of their crowns and their rapid growth, are more effective for windbreaks than others. Since more coniferous trees retain their foliage throughout the entire year, they afford protection in winter as well as in summer. Such species as western yellow, Scotch and Austrian pine grow rapidly, are hardy, and serve the purpose well. In regions of abundant moisture Douglas fir or Norway and Sitka spruce are unequaled. European larch has also been 
very successful in many regions, but, unlike most conifers, it sheds its leaves in winter. Where a windbreak is to consist of a single row only, it should be of a densely growing type that branches close to the ground. For low breaks of this character the Russian mulberry and Osage orange are excellent.

Trees for woodlot or windbreak planting can be purchased from commercial nurserymen or grown by the farmer. Many growers of orchard trees, particularly in the states in the middle West, do a large business in forest tree seedlings. Since the transportation charges are often high, and since most farmers can give the attention and labor necessary to raising the trees themselves without inconvenience or extra expense, it is often desirable for them to do so. The Forest Service of the U. S. Department of Agriculture has issued several publications containing full directions for the establishment of nurseries, and these can be obtained from the Superintendent of Public Documents, Washington, D. C., free or at a nominal cost.*

Planting may be done in the spring or fall, the latter being often preferable in regions where a dry season occurs early in the summer. For plantations of broadleaf species, one-yearold seedlings are best suited, while coniferous species should be two to three years old. The chief points to remember in setting out the trees are not to allow the roots, particularly of coniferous trees, to dry out; to dig the holes large enough to enable the roots to take a normal position without doubling up, and to pack the soil firmly around them. Where planting is done on open ground, it is highly advantageous to plow and harrow the soil before setting out the trees in order to preserve the moisture and kill weeds and sod.

Willows, cottonwoods and other poplars are very easily propagated from cuttings. Cuttings should be of strong, healthy wood of the previous season's growth which ripened

- Reprint from Yearbook, Dept. of Agr., 1905, "How to Grow Young Trees for Forest Planting."

Bulletin No. 29, "The Forest Nursery."

Planting leaflets for almost all important forest trees. 
well and did not shrivel during the winter. A good length is 8 to 12 inches, with the upper cut just above a bud. They may be made when wanted and planted with a spade, or if the ground is mellow they can be merely shoved into the soil until only one bud is above the surface and then tramped.

The spacing of the trees is a question largely of utility, with some variation for different species. In general, however, close planting is advisable in treeless regions, since an artificial forest must stand in a dense mass if it is to succeed in the struggle against native vegetation, wind, sunshine, frost and dry weather, A single tree or row unprotected by associates has a poorer chance. Cultivation is the best method of conserving soil moisture. To obtain the best results plantations should be cultivated, if possible, at least during the first few years. The less care the trees are to have, the thicker they should be set in order that they will be close enough to establish forest conditions of shade, litter and underbrush. Thinnings can then be made as they grow and need more room. The material thus obtained will provide an early supply of fuel, stakes and posts. A spacing of $4 \times 4$ feet is common, but this does not allow for cultivation. For this reason $2 \times 8$ feet is preferable. Shelter belts should be planted closely in order to give protection quickly.

\section{Cost}

The cost of planting is not great. Broadleaf seedlings will cost from $\$ 1$ to $\$ 6$ per thousand at the nursery, coniferous plants $\$ 2.50$ to $\$ 10$. If grown at home the cost will be greatly reduced. The preparation of the soil by plowing and harrowing should not exceed $\$ 2$ per acre, and planting from $\$ 2.50$ to $\$ 5$ per thousand, according to the species, the method used and the condition of the soil. 



\section{APPENDIX}

\section{TAX REFORM TO PERMIT REFORESTATION}

\section{LOSS IN IDLE I.AND}

It is of the very highest importance to have that part of our constantly increasing area of eut and burned over forest land which is not more valuable for agriculture put to its only useful purposethe growing of another forest crop. If this is done it will continue to be a source of tax revenue, to employ labor and support industry, to supply our forest needs, to bring revenue into the state, and to protect our streams. Otherwise it will become a desert, non-taxable, non-productive, a fire menace, and in every way worse than a dead loss to the state in which it exists and to the country at large. In the one way it will be of use to every citizen, whatever his occupation; in the other it will be a burden upon every citizen.

The realness and directness of this problen in the Pacific Northwest is seldom realized. Our deforested areas are great and growing, but of even more peculiar significance is our unparalleled opportunity for making them quickly profitable to the community. Forest growth is more rapid and certain than elsewhere. A heavy crop may be had again in from 40 to 60 years. It will hardly be of the quality of that now being eut, but considering the shortage then to prevail should bring fully as much wealth into the state from its manufacture, the majority to be circulated as payment for supplies and labor. Since, therefore, our denuded land should in 60 years or less bring in again as much as it has already, its idleness costs us each year a sixtieth or more of that immense sum, amounting to a great many millions of dollars annually. To this loss is added the loss of tax revenue which the new crop would yield, with countless indirect injuries.

\section{The OWNer's Compulsory AtTitude}

For this situation our system of taxation is chiefly responsible. The owner may or may not hold the land for a time under the present system, in the hope of selling it or of tax reform, but he will seldom if ever take any steps to insure reforesting, because to do so is too 
likely to be at an actual loss. Whether he has made money on the original erop has no bearing; nor has his being rich or poor, resident or alien. His cut-over land presents a distinct problem to him.

In the first place, its sale value represents an investment. He may sell and reinvest the money in any business which looks invitingperhaps in standing timber. Presumably he can get ordinary business returns, 6 per cent or more, and continue to reinvest these returns. Therefore if he leares this money in forest iand for 50 years without return, for every dollar so tied up he must get $\$ 18.42$ at the end of that period if he is to make 6 per cent on the investment. And this applies not only to the present value of the land, but also to any added expense he incurs in modifying his cutting methods, or in replanting, in order to insure reforestation. If both together amount to $\$ 5$ an acre, he must net $\$ 92.10$ at the end of his 50 years in order to make 6 per cent.

So far no complaint can be made. But if the land is to produce a second crop it cannot be left to take care of itself, as it might were it being held for speculative purposes only. It must be protected from fire and trespass. $\Lambda$ nd since the interest and principal invested will amount to so much for so long a period and be totally lost in case of destruction, the protection must be adequate, practically amounting to insurance. The annual cost will vary greatly according to locality, elass of timber, and the enforcenent of fire laws, but will be from 1 cent at the minimum to 15 cents at the maximum in bad seasons. If all cost of protection and administration is placed at only 5 cents annually, for the sake of illustration, this represents another investment constantly increasing and compounding, which, at the end of 50 years at 6 per cent, will amount to $\$ 14.51$ an acre. Consequently, adding that to his original investment which will bave become $\$ 92.10$, he must net $\$ 106.61$ to make his 6 per cent.

\section{How T.IXES ENTER THE PROBLEM}

Let us now consider the influence of taxation. We have assumed the land to be valuable for forest growing only, and in calling his investment $\$ 5$ an acre included some cost of insuring reforestation. Place this at $\$ 2$ and leave a land value of $\$ 3$, to be fully taxed at 30 mills for both state and county purposes, which is perhaps a fair arerage. This represents the third form of his investment, or 9 cents an acre invested annually and left unavailable for 50 years, and will amount at the end of that time, at 6 per cent, to $\$ 26.13$. He has now to clear $\$ 132.74$ an acre, besides being always in danger of total or partial loss from fire, and during all this time has to have the money, made in some other way, to meet all the annual payments. But no injustice appears, for he has been taxed on an equal basis 
with other producers. If his acre yields 20,000 feet (the maximum to expect), worth $\$ 7$ a thousand, he has made his 6 per cent, the community has gained a resource, and every one is satisfied. His land has been taxed fairly and as he now has a crop to sell he ean afford to pay a tax on it also. If it is taxed at 3 per cent, or $\$ 4.20$ an acre, county and state will altogether have received from him the same tax revenue they collect from other forms of property and industry of like value and profit, and received also the other benefits of forest production and of his expcnditure of wages for protection.

But this is just what cannot legally be done under our present tax system. By failure to recognize that the growth produced is a crop, distinct from the land, grown at the owner's effort and expense, and returning no revenue until ripe, the law now compels the repeated annual taxation of the owner's effort to an extent very likely to amount to confiscation. It has been seen that even under the fair system outlined in the preceding paragraph, forest growing is not more than ordinarily inviting and involves considerable risk and capital. Yet it assumed only a fair anuual tax on the land. Under our present system, logically carried out, here is what would happen:

The first year the tax would be the same. The second year a fiftieth of the total fifty-year crop, which we have assumed worth about $\$ 140$, or $\$ 2.80$, would be added to the land; therefore not $\$ 3$, but $\$ 5.80$, will bear the 30 -mill levy, and not 9 cents, but 17 ceuts, actual tax will be paid. The third year the tax will be 25 cents an acre; at the twenty-fifth year it will be over $\$ 2$ an acre. We have seen that even a 9-cent tax amounted to an investment of over \$26 an acre in order to produce the crop. The continual increase of this according to growth would make the investment run into many hundreds of dollars if the same interest is calculated, and in any ease would make reforestation financially impossible.

In actual practice, the increased valuation would probably not be made by the assessor in the manner just described. Instead of determining the rate of growth scientifically and applying it annually, he now makes an ocular reappraisement at considerable intervals. In most cases there is no increased value, for the land does not reforest but is continually reburned. Where it accidentally does reforest, he makes a rough calculation of the value of the seeond growth, based upon no particular system and seldom aliks in different counties. But the principle remains the same and the result differs only in degree. With the most lenient valuation at 10 or 15-year intervals, the addition of material which makes growing forests so different from our stationary mature forests of today is bound; under our present system, to have confiscatory effect. The land owner, so far from being encouraged to establish and protect a new forest, is 
aetually penalized, for he must assume that its expectation value will be taxed annually, perhaps on an exorbitant basis, as soon as it becomes apparent.

If only the value added each year, $\$ 2.80$ in our illustration, were taxed annually, there would be no injustice. The tax would then, in the ease eited, be 9 eents the first year and 17 cents every year thereafter. But this eannot ke ealeulated with suffieient aeeuraey upon our present knowledge of forest growth and under eonditions varying with every trace or aere. Our example, with its several arbitrary factors of growth, tax rate, interest rate, and future stumpage price, was merely for the purpose of illustration. Furthermore, sueh a solution would stili be illegal under our present laws.

\section{Requirements Reform Mús' Meet}

'These facts are recognized by all students of forestry and taxation. In all eountries where forests are grown the general property tax has been abandoned. Disinterested authorities of every class, approaching the subject only from the publie's point of view and holding no brief for the timberland owner, unite in saying emphatically that its application to growing forests will retard or prerent forestry in our eountry. These authorities include statesmen like Roosevelt and our most prominent governors and senators; expert authorities on taxation generally, like state, national, and international tax conferenees and professors of ecoromies in the leading universities; forestry authorities like Graves, Pinchot and State foresters; and all the many assoeiations and eongresses devoted to such subjects.

These authorities all agree that the forest crop should not be taxed till harvested, but differ somewhat as to the degree to which tho public need of reforestation warrants deferring part or all of the land tax also. This Assoeiation, after careful study of the subject, including European methods, the experiments made by several of our States, and the plans propused by many others, believes the following objects should be sought:

1. Greater permanent rerenue to state and country than is possible under the present system of destroying the taxable souree.

2. Sustention of present revenue to the highest degree compatible with permanenee.

3. Assurance that the owner will ảo his fair part to make the land produetive.

4. Assuranee to the owner in return that future action by the community will not confiscate all profit resulting from his effort.

5. Division of risk, so both owner and community will seek highest production and safety from fire.

6. Demonstrable justice to all coneerned, rather than subsidy whieh, 
while doubtless warrantable to secure the public good, affords less precise basis of legislation at the present time.

7. Simplicity in adoption and operation.

\section{A Suggested Solution}

These requirements can be met by legislation, following constitutional amendment where necessary, providing that where the owner of cut or burned-over land will contract with the State to insure reforestation and protection for a specified term of years, the Stato shall notify the county assessor that the lan $\pi$ is separated for taxation purposes from any forest growth thereon. The land may continue to pay a fair dependable tax, but the crop shall not be taxed until harvested. To the end that cutting of standing timber shall be couducted so as to place the land in the best condition for reforesting, uncut forest land should be subject to examination and similar contract, and the separate classification for taxation should take effect within a year after the timber is removed in compliance with the contract.

This would mean that when the owner of deforested land chiefly valuable to the community for forest production agrees to make it produce, he shall be taxed not on his effort but upon the results of his effort, and then exactly as other producers are taxed upon their results. He may pay tax upon his land, as other land owners do, upon its actual value, but without this value being enhanced for taxation purposes by reason of any crop thereon.

\section{Comparison With Present System in Results}

The community would get no less tax revenue, but presumably more, than it does under the present system. In either case the owner will really pay annually only upon the land value, not upon the growth; the only difference being that under the proposed system he would not be asked to, wbile under the present system either there will be no growth to tax, or, if there is, he cannot afford to pay and the land will revert. It must be borne in mind that while cut-over land is actually being held under the present system, it has seldom grown anything yet. No expense has been incurred to establish a crop, accidental growth is almost always destroyed by fire because it does not pay to protect it, and if it is not so destroyed it has not yet been accorded the expectation value which the assessor will be obliged to recognize in the early future if he really observes the present law. The inevitable tendeney of the present system is continuance to pay on the land with speculative value for purposes other than forestry but abandonment of land valuable only for forestry, with destruction of the forest growth in either case, by purpose or negligence, because 
it means added cost of holding with no possibility of profit. Since the owner cannot be compelled to grow timber to be taxed at his net loss, no timber tax at all will be received by the community and its annual land tax will be confined to land worth holding without timber for purposes other than timber growing. Unảer the proposed system, the latter class would pay the same annual tax, the annual tax revenue from strictly forest land would be greater, and in addition to both would be the future yield tax upon the crop.

\section{An ObJection Met}

A possible superficial eriticism may be that, leaving the land out of consideration, the proposed yield tax at a personal property valuation of the crop means that but one year's tax is to be paid upon the timber. The fallacy of this, however, will be seen when it is remembered that it is a crop, baring been produced from nothing by the owner, since his acquisition of the land and while he was paying taxes upon his land upon its value for productive purposes throughout the entire period just as any other crop grower does. It is not unearned speculative inerement. To tax it annually is exactly equivalent to taxing an agricultural erop 50 times during its growing period. The proposed plan does tax the annual production fully, although not until the crop is produced, for taxing its full value when grown is the same as taxing each year the increment added since the preceding year. If it is worth $\$ 150$ an acre, after 50 years from seed, a 3 per cent yield tax would be $\$ 4.50$. Each year since the first must have produced a fiftieth of the ultimate value, or $\$ 3$, and had this been taxed at 3 per cent, or 9 cents, the same aggregate revenue of $\$ 4.50$ would have resulted. To also tax annually the value of proceding years' production, like taxing a wheat crop twice a week, is exactly the confiscatory prohibition of forest growing which we should seek to avoid.

When the essential difference of the two systems is grasped-that the crop is distinct from the land and the latter is still fully taxedit will be seen that but one tax upon the crop, at the rate other property pays, is all that is just and all that can possibly be paid in a competitive commercial business. The ease is not analogous with our present system of taxing mature timber, in which land and timber together are assumed to constitute inseparable realty, stationary in production and increasing only speculatively in value, therefore the comparison with one year's taxation under our present system has no weight.

\section{From the OWner's Standpoint}

Nor does the proposed system by any means either subsidize the forest grower or assure him a profit. It merely puts on a basis 
similar to that of other enterprises a business more greatly handicapped by long-deferred returns, risk of loss, uncertainty of future prices, and continued current expense without current revenue. Only escape from fire and high future stumpage prices will permit profit at best. Otherwise, since the tax is definite and not upon income, the forest grower will pay the community for the honor of providing it a resource at his own expense.

It is believed, however, that a more fortunate outcome is suffieiently promised in this region of rapid growth if we remove the single fatal handicap of uncertain confiscatory taxation.

\section{VIEWS OF EXPERT AUTHORITIES}

THEODORE ROOSEVEL: Second only in inportance to good fire laws well enforced is the exactment of tax laws which will permit the perpetuation of existing forests by use.

GIFFORD PINCHот: Land bearing forests should be taxed annually on the land value alone, and the timber crop should be taxed when cut, so private forestry may be encouraged.

North American Conservation Conference, Washington, D. C.: Believing that excessive taxation on standing timber privately owned is a potent cause of forest destruction by increasing the cost of maintaining growing forests, we agree in the wisdom and justice of separating the taxation of timber land from the taxation of timber growing upon it, and adjusting both in such manner as to encourage forest conservation and forest growing.

The private owners of land unsuited to agriculture, once forested and now impoverished or denuded, should be encouraged by practical instruction, adjustment of taxation, and in other proper ways, to undertake the reforesting thereof.

GiFford Pinchot,

ROBERT BACON,

J $\triangle$ MES R. GARFIELD,

Commissioners representing the United States.

SYDNEY FISHER,

Clifford Sifton,

HENRI S. Boland,

Commissioners representing the Dominion of Canada.

ROMULU Escobar,

Miguel A. De Quevedo,

CARLOS SELLerier,

Commissioners representing the Republic of Mexico.

E. H. OUTERBRIDGE,

Commissioner representing the Colony of Newfoundland. 
Fred. R. Fatrchild, Professor of Ecomomies, Yale University, member International Tax Conference: Probably nothing more effectually discourages investment than uncertainty as to future costs. And whatever may be said of the present system of taxation, there can be no question of its arbitrariness and uncertainty. If to all the other risks of forestry we add uncertainty as to what the taxes are going to be, we cannot blame investors for some hesitation in embarking on an enterprise which may have to pay taxes fifty years before the returns come in. And more than this; the investor cannot safely base his calculations on the continuance of the present lenient administration of the property tax. As has been shown, the tendency today is toward a stricter enforcement of the law and a heavier burden of taxation.

State constitutions stand today in the way of many plans for reform in State and local taxation. The movement toward their amendment is growing as part of the general programme of tax reform.

The real problem of forest taxation is in connection with the future of our timber lands rather than with their past. The preservation of the forests is a mattei of the utmost importance. So far our forests have been exploited with little or no regard for the future. But the present methods eannot last much longer. Forestry must come some time, and its early coming is a thing greatly to be desired. And whenever we are realy to seriously undertake it we will find our presenit methods of taxation a severe handicap. Strictly enforced, according to the letter of the law, the annual tax on the full value of the land and standing timber is almost sure to result in excessive taxation, and the timber errner eannot count on the continuance of the present lenient enforcement of the law. Even if the tax might not be excessive, its uncertsinty would be a serious obstacle to investment. We ean hardly hope to see the general practice of forestry as long as the present methods of taxation continue.

To be equitable, taxation of timber lands like taxation of anything else should be based on ineome or earning power.

With regard to its effect on revenue, there is little to be feareci from the tax on yield. Eventually, revenue will be increased by a method of taxation which does not prevent the cicvelopment of forestry. Forests paying a moderate tax are better than waste lands abandoned and paying no tax at all.

The tax on yield has many decided advantages. It avoids the evils of the general property tax. It is equitable and certain. It is in harmony with the peculiarities of the business of forestry, and will be a distinct encouragement to the practice of forestry. Its adoption by the States wonld remove one obstacle to the perpetuation of the nation's forest resources. 
National Conservation Commission, appointed by the President of the United States: It is far better that forest land should pay a moderate tax permanently than that it should pay an excessive revenue temporarily and then cease to pay at all.

We tax our forests under the general property tax, a method of taxation abandoned long ago by every other great nation. In some regions of great importanee for timber supply, and in individual cases in all regions, the taxation of forest lands has been excessive and has led to waste by forcing the destructive logging of mature forests, as well as through the abandonment of cut-over lands for taxes. That this has not been even more general is due to under-assessment, to lax administration "of the law, kut to no virtue in the law itself. Already taxes upon forest lands are being increased by the strict enforcement of the tax laws. Even where this has not yet been done, the fear that it will be done is a bar to the practice of forestry.

We should so adjust taxation that cut-over lands can be held for a second erop. We should recognize that it costs to grow timber as well as to log and saw it.

From now on the relation of taxation to the permanent usefulness of the forest will be vital. Present tax laws prevent reforestation on cut-over lands and the perpetuation of existing forests by use.

United States Forest Service: It is evident that the old method of taxing forest property, as well as other property, at its supposedly full value will, as the value of timber increases and is recognized, put a premium on premature and reckless cutting, and will hinder any effort to reforest cut-orer lands. No business man will engage in an undertaking where the returns are so long deferred and the risks are uninsurable unless he can estimate the probable expenses and a reasonably large profit. That the forests themselves, irrespective of their ability to stand taxation, are of great value to the communities in which they are loeated, for water protection, lumber supply, and seenery in resort regions is undoubted.

The fundamental difficulty is that the tax should be in proportion to yield or income and not in proportion to the market value of the land and standing timber. Economists are substantially agreed that this principle is applicable to the taxation of all kinds of property with certain exceptions. Where there is a reasonably certain annual yield or income the market value is theoretically dependent upon it. A woodlot or forest, however, usually in this country has no annual yield. It is unjust to require the owner to carry the full annual burden of taxes, risk and protection in every year for the ehance of a yield once in fifty years, and it is impossible for the owner to do it, for the taxes with compound interest would confiseate his entire capital. 
International Tax Confrerence, held at Toronto: Resolved, That it is within the legitimate province of tax laws to encourage the growth of forests in order to protect watersheds and insure a future supply of timber; and legislation, or constitution anendment where necessary, is recommende 3 for these purposes.

American Forest Congress, Washington, D. C.: Resolved, That we earnestly commend to all state authorities. . . reducing tho burden of taxation on lands held for forest reproduction in order that persons and corporations may be induced to put in practice the prineiples of forest conservation.

Pennsylvania Department of Forestry: Tax assessors have differing ideas of value and their assessments vary widely. The only remedy for the forest owner is to appeal from the assessment to the eounty commissioners, and, if here unsuceessful, to the county court, a matter involving both time and expense and frequently more costiy than the differences in taxes to be gained; but at the same time the fact is well reeognized that forested land is both unequally and unfairly taxed.

H. S. Graves, Chief Forester for the United States: The forest areas now owned chiefly by lumber eompanies will eease to be devastated as soon as fires are stopped. They will not, however, be handled to any large extent with a view of future production until the taxes are placed on a fair basis.

Filibert Roth, Professor of Forestry, University of Michigan, State Fire Warden of Michigan (speaking of frequent local attitude toward non-resident owner):

Though, in truth, these resident people often make their living from the tax money of the non-resident, and though the latter contributes toward every rod of road and every schoolhouse built, and other improvement, yet he is treated as if he were a wrongdoer, is taxed unmereifully, and, in addition, a trespass on his land or forest is excused and it is almost impossible in many places to get convietion.

If the State and local people had treated the owners of timber honestly and had spent a reasonable part of the taxes in giving the protection which the owner had a right to expect under the Constitution, there would still be more than half of our pinery lands covered by forest.

Forestry is no "sugar trust baby," as so many are trying to make it out. Forests can pay taxes as well as any other property. Forestry is like any other honest business, it cannot stand confiscation.

Suppose you have a twenty-acre lot of sugar beets and the assessor would hang around until the beets are ripe and then figure: "The land is good; I assess it at $\$ 75$ per aere, and the crop is worth $\$ 75$ more, so that this property will stand at $\$ 150$." What would you say? But the assessor who assesses the timber as part of the real 
estate and assesses the same crop of timber year after year does precisely this thing. He assesses land and crop for the owner of a woodlot and forest, while for all other farmers he assesses only the land.

Let the State pass a few simple laws; provide for the protection of forest property as we provide for other property; prevent confiscation under the guise of taxation; stop foreing its poor tax lands on the market, and go ahead with a good example on its own lands, and instead of holding them in a waste land condition protect them and grow timber.

A. T. Hadley, President Yale University: We have it in our power to make intelligent forestry by individuals more profitable. The margin between business that succeeds and business that fails is a narrow one, and by just covering that margin by differences in tax laws, by differences in protective laws, by laws for the prevention of fires, we can make profitable an industry which the public needs, but which today is unprofitable.

JAMES O. DAvidson, Governor of Wisconsin: It is to be hoped that laws will be passed encouraging owners to cut timber conservatively under forestry regulations, rather than oblige them to cut as quickly as possible to escape the injustice of taxation.

Professor F. G. Miller, University of Washington: Next to fire the most serious handicap to the progress of forestry is our unjust method of forest taxation. Laying as we do a yearly tax on both the growing crop and the land, the burden of taxation makes the holding of land for a second crop prohibitive as far as the private owner is concerned.

The farmer pays a yearly tax on his land, and a tax on his erop each time he harvests one. This is usually annually. However, if through drought, insect invasion or other misfortune he loses his erop, he is not called upon to pay a tax upon it.

Senator ReEd Syoot, of Utah, Chairman Section of Forests, National Conservation Conmission: One of the urgent tasks before the States is the immediate passage of tax laws which will enable the private owner to protect and keep productive under forest those lands suitable only for forest growth. In our discussion in committee meeting there was a question raised by a member present as to this recommendation, claiming that it would encourage great monopolies in securing larger holdings of timber, if an annual tax was not required on the timber itself. I hare studied this question in foreign lands, particularly in Germany and Switzerland, and I find that the result has been exactly the opposite. It is a short-sighted policy which invites, through excessive taxation, the destruction of the only crop which steep mountain lands will produce profitably. 
Taxes on forest land should be levied on the erop when eut, not on the basis of a general property tax-that unsound method of taxation long abandoned by every other great nation.

Governor Newton C. Blanchard, of Lonisiana: Under the present tax laws of many of the States large assessments are put on timber lands, and this is foreing timber londers-the owners of the sawmills-to eut off that timber too rapidly. At least it is having mueh effect that way. Give them the eneouragement to hold back and not force their produet upon the marketz, and then exempt, by a system of wise tax lairs, eut-over lands devoted to purposes of reforestation.

Maryland State Board of Forestry: The present method is to assess woodlands under the general property tax, making the assessment high where the timber is valuable and plaeing it low where the timber has been eut off. There is in the operation of this system a tendeney to eut off the timber before it reaches maturity to avoid the high rate of taxation. A premium is placed on forest destruction and a penalty on forest eonservation.

The growth of timber is slow and under present stumpage prices and rates of taxation there are eomparatively few cases where the sale value of the erop equals the cost of growing it, if a fair rental for the land is considered. It is true that most of the forests are on lands that could not be used for anything else, but it is not fair to expeet the landowner to produce timber which is a publie necessity, the use of which is only less unirersal than food erops, at a finaneial saerifice. Increasing prices and better fore managenent are reliev. ing the situation to some extent, but the most effeetive, as well as the most equitable way, is through a ehange or modification of present tax laws.

Professor Edwin R. A. Seligman, Columbia Uuiversity: The general property tax as aetually administered is beyond all doubt one of the worst taxes known in the eivilized world. Beeause of its attempt to tax intangible as well as tangible things, it sins against the eardinal rules of uniformity, of equality, and of universality of taxation.

Professor Alfred Akerman, Georgia University: One reason why it (the general property !ax) is so outrageous in practice is that it is wrong in theory. The mere possession of property may or may not be an index to the ability of the owner to pay tax. It all depends on whether the property brings ineome.

Allen Hollis, Secretary Soeiety for Protection of New Hampshire Forests: Taxation today, in my opinion, is the greatest menace to forest preservation.

One prineiple is absolutcly sound-we all know it, and what we 
have to do is to make everybody else know it-and that is, that the annual taxation on a crop which is constantly increasing in value each year means confiscation of that property.

It is submitted here that no single factor bears so definitely upon the future of our forests as this constitutional requirement of equality in taxation. As a business proposition, no one can afford to hold woodlands and pay annually 2 per cent upon their actual value, increased each year by growth and advancing prices, during the fifty to one hundred years necessary for maturing the crop.

Charles Lathrop PaCK, Director American Forestry Association: While the nation and the State are working to devise ways and means of conserving our forest resources, we are at the same time, in a real sense, taxing our timber to death.

Our present tax laws prevent reforestation on cut-over lands and the perpetuation of existing forests by proper use and economic eutting.

State of Michigan Forestrity Commission (extracts from report to governor): The system of taxation should be modified so as to stimulate timber production instead of repressing it.

There is no logical, moral or political reason why a crop of growing trees should be included in the assessment, in addition to the actual value of the land, that does not apply with equal force and reason to farm lands which are continuously cropped with grains, root erops or hay. The uncertainty of realizing upon a tree crop is very much like the uncertainty of a given farm's producing its erop in full. The only difference is that the forest crop is subjected to the vicissitudes and chances of a long series of years, while the farm erops are subject only to the vicissitudes of about one year. Many of the erops are only subject to the accidents of five or six months.

In the present stage of forestry in this country, what is most imperatively required is such a treatment of the subject of taxation of forested lands as will induce private owners to retain their forests until ripe to the harvest and to reforest denuded lands. This would apply to those having lands suitable for such purpose, or others who might purchase lands suitable therefor, who, under the present diverse, and oftentimes inequitable, practice of assessments, cannot be induced to make investments of that character.

Report of Society for Protection of New Hampshire Forests, Ex-Governor Frank W. Rollins, President: The law of New Hampshire requires that all property shall be taxed equally, aceording to its value, a law constautly and necessarily violated by assessors of forest property throughout the State. Its strict application even for a short period would go far to rid the State of its standing timber. The reason for this is that timber is a growing crop-the 
only crop taxed more than once, and if taxed annually at its full value the cost to the owner of holding the property would be so excessive as to require its hasty disposal. Assessors everywhere feel instinctively the inherent injustice of taxing a growing erop at a high annual rate, and violate the law and their oaths of office with impunity. The result is there are as many systems of forest taxation in the State as there are assessors, and glaring inequalitics exist, not only between neighboring towns, but also in some instances between different parts of the same town.

The unequally high rate placed upon the timber of non-residents is wholly iniquitous.

New Hampshire State Grange, Committee on Agriculture: Many of the towns in our State invite the misuse of forests by overtaxation. This should be guarded against. By reasonable thrift we ean produce a constant wood and timber supply beyond our own need, and with it conserve the usefulness of our streams for water supply, navigation and power, and at the same time increase the value of our farms.

E. M. GRIFrith, State Forester of Wisconsin: The present method of taxing timberlands is hostile to the forestry interests of the State, as a single timber crop is taxed heavily and repeatedly, and the owners are forced by our present laws to cut their mature timber in order to escape inequitable taxation, to sacrifice their young growth, and to disregard conservative methods of forest management.

Taxes are unfortunately a very valid reason in many sections of the State for not practicing forestry. Many town assessors seem to feel that they must tax the timberland owner, especially the nonresident owner, as heavily as possible, and naturally in self-defense the owner is forced to cut his timber and so reduce the taxes to a reasonable amount. Then, when it is too late, the towns find that they have "killed the goose that laid the golden egg." However, the loss of the taxes on the timber is but a drop in the bucket compared to the irreparable damage to many comnunities from losing the industries which depended uupon the forests for their raw material. To appreciate this one only needs to visit towns in which the sawmills have shut down on account of lack of timber.

Of late years the end of the timber has been largely hastened on account of the excessive taxes placed upon it. The whole system of forest taxation in this country is wrong, for it puts a premium on forest destruction.

RALPH C. HAWLEX, Instructor in Forestry, Yale University: A system of taxation which discriminates against timber, one of the chief natural resources of the commonwealth, is to be condemned.

Kentucky State Department of Agriculture Report: When 
a rise in the valuation of other than forest property becomes necessary because of the greater development of the resources of the region, the valuation of forest property should be increased wilh great caution in order that the forest lands may be held to advantage for the production of future timber crops. A timber crop is marketed only after the young growing timber has been held for a long term of years, during which time the forest has been yielding only a very slight revenue, if any, to the cwner. If the valuation of the forest or its rates of taxation goes beyond a comparatively low limit, the holding of forest land for a second crop of timber is impracticable or nearly prohibitive. This condition has prevailed in many other States where now the problem of taxation is a difficult one to solve.

ALFRED GASKILL, State Forester for New Jersey: The present practices favor and encourage the untimely or wasteful use of standing forests, discourage the propagation of others, and tend to hasten the time when the country shall be forced to face a wood famine.

It would be impossible to apply the European system here with anything like the exactness that attaches to it in the old countries, because we have not the means of knowing the true worth of forest soil or of forest crops, but the principle is applicable anywhere. Even in the hands of non-expert assessors it gives a fairer basis of valuation than our present method, and in the long run will insure larger returns.

J. E. Frost, Tax Commissioner of Washington: The State's system of taxation is obsolete, and only 13 civilized communities in the world have such an out-of-date system. The State is confined by the constitution to property tax, well known as a primitive system, utterly incapable of coping with modern business. It can be remedied only by recognizing the different classes of taxable property.

Dr. Francis L. McVex, University President and Tax Expert: Under the old plan of valuing annually the property it was difficult to secure an appraisement that was satisfactory to anybody and, what was more, as the years went by the local governments found their assessed values decreasing and the burden of government materially increasing with the decline in amount of standing timber. The annual taxation of the land upon which the timber stands meets this difficulty, while the taxation of the product at the time of harvesting provides a plan that is fair both to the local government and to the owner of timber.

Colorado Conservation Commission: Resolved, That it is the sense of the Colorado Conservation Commission that the governor and legislators should submit to the people at as early a date as possible an amendment to the constitution, exempting from taxation 
lands devoted solely to the growth and culture of new timber, and if such amendment is adopted, the same to be followed by suitable legislation.

Oregon State Conservation Commission: Constitutional amendment and legislation should be invoked to permit it low fixed tax on cut-over land during the period of no return to the owner, the State to be compensated by a tax on the crop when cut. Obviously this inducement should be offered only to thcse holders of cut-over land who will reciprocate by furthering the object sought. The result of such a system would be not only perpetuation of the forest and its attendant industries and payroll, but also a far greater tax return than the present one of encouraging potential forest land to become worthless and non-taxable.

Legislature of Minnesota: "Sec. 17a. Laws may be enacted exempting lands from taxation for the purpose of encouraging and promoting the planting, cultivation and protection of useful forest trees thereon." This is the text of an act amending the Minnesota constitution passed by the legislature.

Washington Conservation Association, Walla, Walla: Whereas, The question of holding cut-over forest land for a second crop is of paramount importance to the State, and

Whereas, This is made impossible on the part of private owners by our present method of forest taxation, whereby the owner is obliged to pay an annual tax on the land as well as an annually repeated tax on the same growing crop, therefore be it

Resolved, That this convention favors such remedial legislation as will encourage reforestation of privately owned lands, and be it further

Resolved, That it is the sense of this convention that as applied to reforestation such remedial legislation ean be secured by a plan which will levy an annual tax on the land anũ an income tax on the forest crop only when the crop is harvested.

First National Conservation Congress, Seattle: Resolved, That we urge the adoption of a system of taxatiou under which woodlanis will pay a moderate annual land tax and the timber will be taxed only when cut. 


\section{THE}

\section{WESTERN FORESTRY AND CONSERVATION ASSOCIATION}

The Western Forestry and Conservation Association has no individual membership, but consists of and represents all organized agencies for forest protection in the States of Montana, Idaho, Washington, Oregon and California. Following is Article IV of its constitution:

"Any association formed for the purpose of organized effort in the protection of forests from fire and for the reforestation and eonservation of the forest resources of the States represented shall be eligible for membership. Any organization admitted to menbership shall be entitled to two votes in the meetings of tbis Association. The chief forest officer of each of the five States embraced, and of each district of the United States Forest Service embraced, shall be honorary members."

The allied organizations are at present fifteen in number: The Oregon Forest Fire, Oregon Conservation, North Willamette Forest Fire, Coos County Fire Patrol, Northwest Oregon Forest Fire, Klamath Lake Counties Forest Fire, Polk-Yamhill Forest Fire, Lincoln-Benton Forest Fire, North Idaho Forestry, Washington Forest Fire, Washington Conservation, Inland Forest Fire, Potlatch Timber Protective, Clearwater Timber Protective, Pend d'Oreille Timber Protective, Coeur d'Alene Timber Protective and Northern Montana Forestry Association.

The purpose of the Western Forestry \& Conservation Association is to promote forest fire prevention, conservative foresi management, reforesting of eut-over lands not more valuable for agriculture, improvement in taxation systems, preservation of stream flow, and all other things comprehended by forest conservation.

Its meetings enable representatives of the allied associations and of State and government to exchange ideas and levise ways and means for carrying on these movements in harmony along practical and effective lines. It also affords means of collecting and distributing information from these several sources.

It believes in the use of every legitimate means of publicity and education to interest lumbermen, legislators and public, not only in paving the way for future advance, but also in such actual, workable, conservation measures as can be put into practice immediately.

To this end, believing action speaks louder than words, it practices what it preaches. While fully recognizing the great value and necessity of associations devoted entirely to propaganda, it sees also 
a need of reducing theory to a sound business basis. Either as associations or through their members the forest protective associations it represents spent about $\$ 700,000$ in 1910 for patrol and fire fighting to protect the forests of the West. They safeguarded millions of acres of timber, put out many thousand fires, and saved forest resourees worth billions of dollars to the community. As a result of their effort the losses in Idaho, Washington and Oregon were kept down to about a quarter of 1 per cent of the privatelyowned timber in these States, and this notwithstanding that it was one of the worst fire years in American history.

While they unite in tho Western Forestry and Conservation Association, and levy a special assessment to support its work, the local organizations are wholly independent in their actual forest fire work. Their systems vary slightly, but the majority follow the general plan outlined on pages 100-103 of this booklet.

One of the primary objects and ambitions of the Association is to extend this effort until all the timber owners in the five States do their part and every acre of pricate forest land is brought under a highly trained and organized sorvice. If the States themselves lend aid and backing this can be made the most efficient fire service in existence, as the most magnificent body of standing timber in the world deserves.

The Association also employs a trained forester to assist its meinbers who control timber to install and maintain improved methods of protection, eutting and reforestation. In this way it not only helps those who will to really accomplish the end in view, but by publishing such material as is contained in this booklet makes the experiments serve as object lessons to others.

Perhaps the most unique function of the Association is to furnish the only common meeting ground and clearing house for the many public and private agencies for forest protection. At its meetings Federal and State officiais, representatives of public conservation associations and timber owners join on equal footing, without controversy over rights or authority, in discussing practical details of how to accomplish the best results together under couditions as they exist. Every man present is there because he wants to do his part, with his own hands or mowey, to preserve the forests of the West. He knows what he is talking about and the others aro glad to hear him. The result is a nutual understanding and coöperation along practical lines which is of immense benefit to the public whose welfare depends largely upon these agencies that really control its forest resources. 




SOUTHERN BRANCH, UNIVERSITY OF CALIFORNIA,

LIBRRARY,

LOS ANGELES, CALIF, 
$8 \frac{1}{3}$
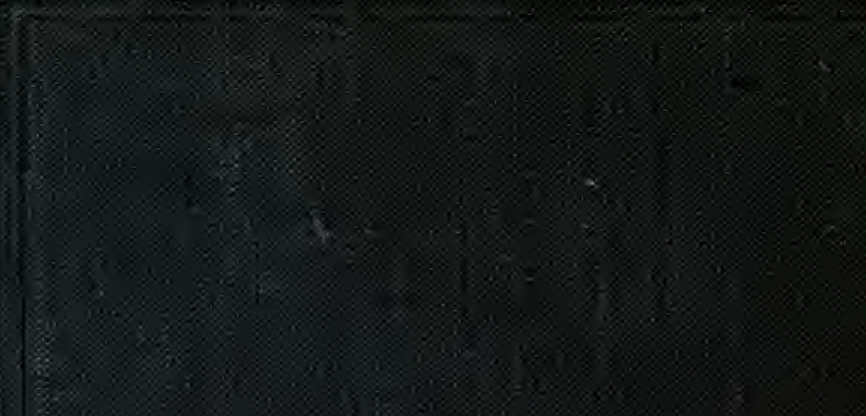

woros

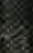

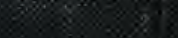
28. 